PNL-7712

UC. 350

\title{
Adoption, Implementation and Enforcement of Commercial Building Energy Codes in New Mexico and Arizona
}

J. W. Callaway

A. G. Thurman

D. L. Shankle, Project Manager

July 1991

Prepared for the U.S. Department of Energy under Contract DE-AC06-76RLO 1830

Pacific Northwest Laboratory Operated for the U.S. Department of Energy by Battelle Memorial Institute 


\title{
DISCLAIMER
}

This report was prepared as an account of work sponsored by an agency of the United States Government. Neither the United States Government nor any agency thereof, nor Battelle Memorial Institute, nor any of their employees, makes any warranty, expressed or implied, or assumes any legal liability or responsibility for the accuracy, completeness, or usefulness of any information, apparatus, product, or process disclosed, or represents that its use would not infringe privately awned rights. Reference herein to any specific commercial product, process, or service by trade name, tradcmark, manufacturer, or olherwise does not necessarily constitute or imply its endorsement, recommendation, or favoring by the United States Government or any agency thereof, or Battelle Mernorial institute. The views and opinions of authors expressed herein do not necessarily state or reflect those of the United States Government or any agency thereof.

\author{
PACIFIC NORTHWEST LABORATORY \\ operated by \\ BATTELLE MEMORIAL INSTITUTE \\ for the \\ UNITED STATES DEPARTMENT OF ENERGY \\ under Contract DE-ACO6-76RLO 1830
}

Printed in the United States of America

Available to DOE and DOE coniractors from the

Office of Scientific and Technical Information, P.O. Box 62, Oak Ridge, TN 37831;

prices available from (615) 576-8401. FTS 626-8401.

Available to the puhlic from the National Technical Information Service,

U.S. Department of Commerce, 5235 Port Royal Rd., Springfield, VA 22161. 
PNL-7712

UC-350

\section{ADOPTION, IMPLEMENTATION AND ENFORCEMENT OF COMMERCIAL BUILDING ENERGY CODES IN NEW MEXICO AND ARIZONA}

J. W. Callaway

A. G. Thurman

D. L. Shankle, Project Manager

July 1991

Prepared for the U.S. Department of Energy under Contract DE-AC06-76RLO 1830

Pacific Northwest Laboratory

Richland, Washington 99352 



\section{SUMMARY}

The U.S. Department of Energy (DOE) is considering ways to encourage states to adopt energy efficiency standards for residential and commercial buildings in the private sector. Such standards are now mandatory for federal buildings, and for private buildings in $\mathbf{3 4}$ states; in the remaining 16 states, the standards serve as guidelines for voluntary compliance.

In this study for DOE, Pacific Northwest Laboratory (PNL) ${ }^{(a)}$ assessed the process by which energy codes for commercial buildings were adopted and implemented in Arizona and New Mexico. Information was gathered primarily through a series of interviews with state officials, city building officials, architects and engineers, builders, and staff from utilities in the two states.

Until other state processes are studied, the extent of the similarities and dissimilarities to the situation in New Mexico and Arizona are unknown. Nevertheless, a more extensive study would likely show that at least some elements of the two states' experience have been paralleled in other parts of the country. Thus, the following general strategies to encourage the adoption of energy codes, assist implementation, and support enforcement were developed based on the research from Arizona and New Mexico.

To encourage adoption of a code

- conduct a substantial information campaign on the new standards

- bridge the gap betwcen the new standards' format and content and that typically found in building codes

- develop reliable and easy-to-use implementation tools to support the new standards

- verify the energy savings of buildings constructed to the level of the new standards and reassure the building community that the standards can be met with familiar techniques.

To assist implementation

- develop computer-based design tools for users

- develop and support training and education programs.

To support enforcement

- provide training for building code officials

- develop simplified processes for determining compliance to support the new standards

- offer incentives for architects and builders

- coordinate efforts with utilities' demand-side programs.

(a) Pacific Norhwest Laboratory is operated for the U.S. Department of Energy by Battelle Memorial Institute under Contract DE-ACO6-76RLO 1830. 
PNL also assessed the likelihood that either of the two study states would upgrade its existing code or consider adopting a codified version of the new standard from the American Society of Heating, Refrigerating and Air-Conditioning Engineers, ASHRAE 90.1. Mandatory energy codes are well established and well implemented in New Mexico. Because a code is already established, however, New Mexico may be reluctant to adopt a new and different one.

The potential for Arizona to adopt a new code also appears to be quite low. A surplus of power in Arizona reduces the urgency of energy conservation. In addition, Arizona now has a high rate of vacancy in commercial buildings, and the legislature and state officials do not want to further burden a stagnant industry by passing stringent building codes. 


\section{CONTENTS}

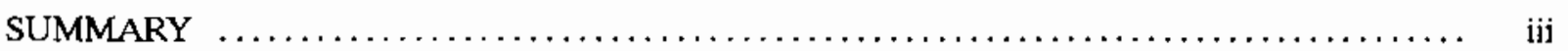

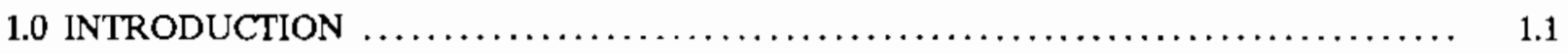

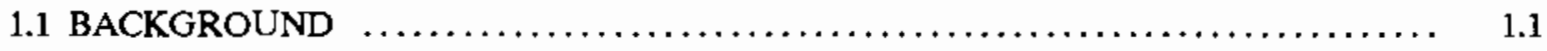

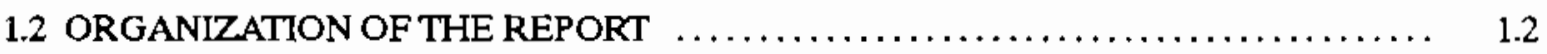

2.0 CONCLUSIONS, RECOMMENDATIONS AND STRATEGIES $\ldots \ldots \ldots \ldots \ldots \ldots \ldots \ldots \ldots$

2.1 CONCLUSIONS ABOUT COMMERCIAL ENERGY CODES IN NEW MEXICO $\ldots \ldots \quad 2.1$

2.2 CONCLUSIONS ABOUT COMMERCIAL ENERGY CODES IN ARIZONA $\ldots \ldots \ldots . \quad 2.2$

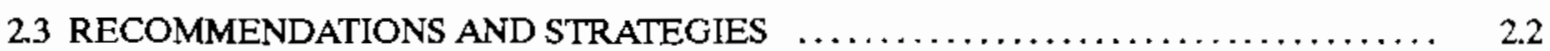

2.3.1 Potential DOE Roles to Encourage Adoption of the New DOE/ASHRAE

Commercial Standards $\ldots \ldots \ldots \ldots \ldots \ldots \ldots \ldots \ldots \ldots \ldots \ldots \ldots \ldots \ldots \ldots \ldots \ldots \ldots \ldots \ldots, 2.3$

2.3.2 DOE's Role in Assisting Implementation of Upgraded Codes $\ldots \ldots \ldots \ldots \ldots \ldots \ldots . \quad 2.4$

2.3.3 DOE's Potential Role in Supporting Enforcement $\ldots \ldots \ldots \ldots \ldots \ldots \ldots \ldots \ldots \ldots \ldots$

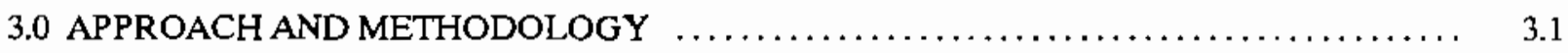

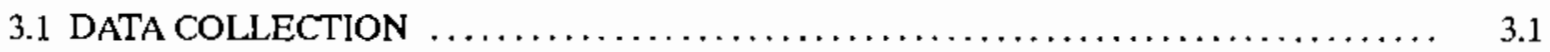

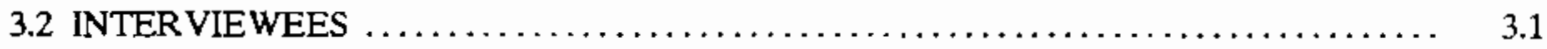

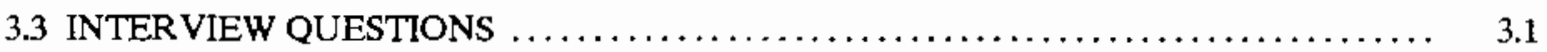

4.0 ADOPTION AND IMPLEMENTATION OF COMMERCIAL ENERGY CODES IN

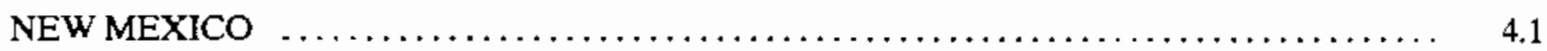

4.1 CURRENT STATUS OF COMMERCIAL ENERGY CODES IN NEW MEXICO $\ldots \ldots . \quad 4.1$

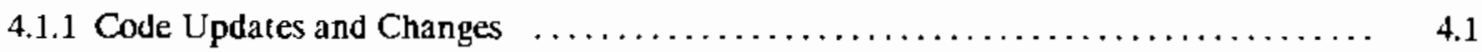

4.1 .2 Code Compliance $\ldots \ldots \ldots \ldots \ldots \ldots \ldots \ldots \ldots \ldots \ldots \ldots \ldots \ldots \ldots \ldots \ldots \ldots \ldots \ldots \ldots \ldots, 4.1$

4.2 ENERGY CODE ADOPTION AND CODE ADOPTION ISSUES IN NEW MEXICO $\ldots \quad . \quad 4.2$

4.2.1 The Building Code Adoption Process $\ldots \ldots \ldots \ldots \ldots \ldots \ldots \ldots \ldots \ldots \ldots \ldots \ldots \ldots \ldots \ldots \ldots \ldots$

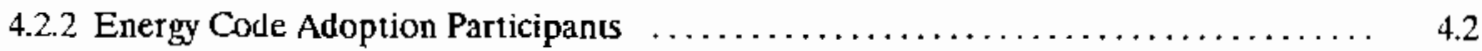


4.2.3 Code Adoption Issues

4.3 CODE IMPLEMENTATION: STATE PERSPECTIVES $\ldots \ldots \ldots \ldots \ldots \ldots \ldots \ldots \ldots .4 .3$

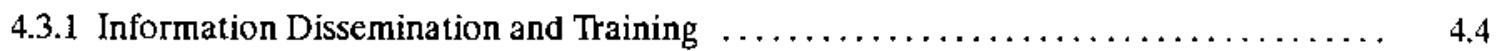

4.3.2 Administrative Impacts of Adoption and Implementation $\ldots \ldots \ldots \ldots \ldots \ldots \ldots \ldots \ldots$

4.4 CODE IMPLEMENTATION: CITY PERSPECTIVES $\ldots \ldots \ldots \ldots \ldots \ldots \ldots \ldots \ldots \ldots .4 .4$

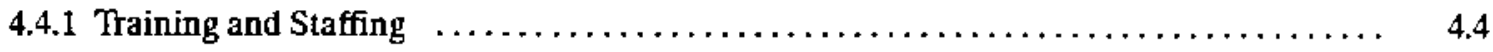

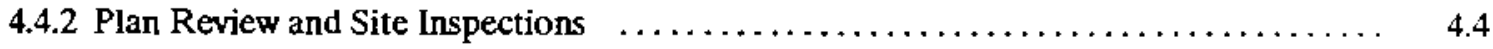

4.4.3 Energy Code Training and Enforcement Resources $\ldots \ldots \ldots \ldots \ldots \ldots \ldots \ldots \ldots \ldots$

4.4.4 Levels of Understanding of Energy Code Requirements $\ldots \ldots \ldots \ldots \ldots \ldots \ldots \ldots \ldots$

4.5 CODE COMPLLANCE: VIEWS OF ARCHITECTS AND ENGINEERS $\ldots \ldots \ldots \ldots \ldots .4 .5$

4.5.1 Code Compliance During Design and Construction $\ldots \ldots \ldots \ldots \ldots \ldots \ldots \ldots \ldots \ldots$

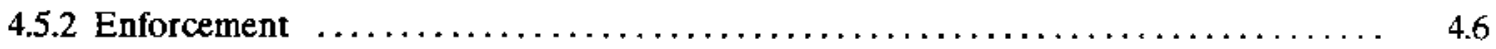

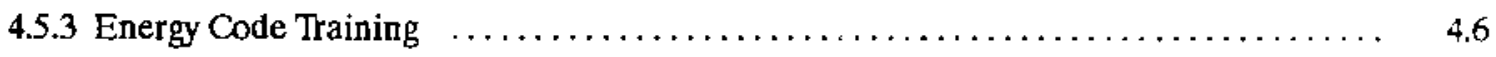

4.6 CODE COMPLIANCE: VIEWS OF BUILDERS $\ldots \ldots \ldots \ldots \ldots \ldots \ldots \ldots \ldots \ldots \ldots$

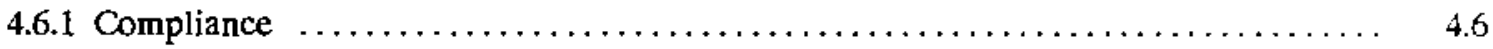

4.6.2 Building Officials' Knowledge $\ldots \ldots \ldots \ldots \ldots \ldots \ldots \ldots \ldots \ldots \ldots \ldots \ldots \ldots \ldots \ldots \ldots \ldots \ldots \ldots \ldots$

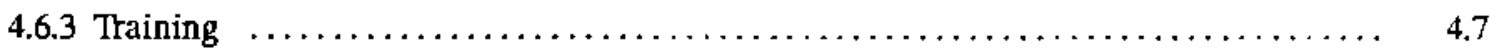

4.6.4 Code Changes $\ldots \ldots \ldots \ldots \ldots \ldots \ldots \ldots \ldots \ldots \ldots \ldots \ldots \ldots \ldots \ldots \ldots \ldots \ldots \ldots \ldots \ldots \ldots \ldots \ldots, 4.8$

4.7 NON-CODE INFLUENCES ON ENERGY EFFICIENT BUILDING PRACTICES $\ldots \ldots \quad 4.8$

5.0 ADOPTION AND IMPLEMENTATION OF COMMERCIAL ENERGY CODES

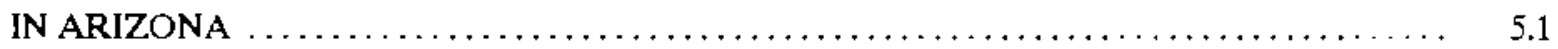

5.1 CURRENT STATUS OF COMMERCIAL ENERGY CODES IN ARIZONA $\ldots \ldots \ldots \ldots .1$

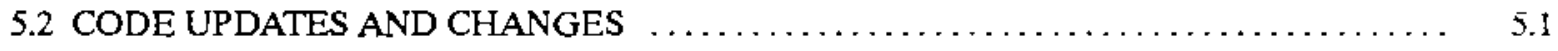

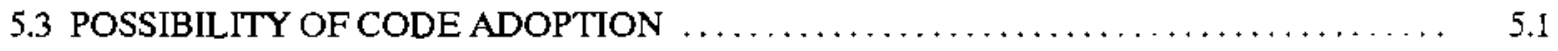

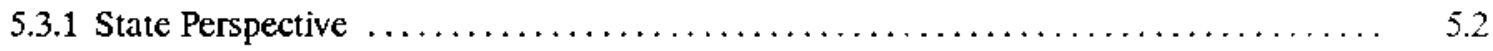




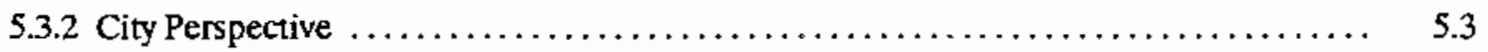

5.3 .3 Impact on Local Building Officials $\ldots \ldots \ldots \ldots \ldots \ldots \ldots \ldots \ldots \ldots \ldots \ldots \ldots \ldots \ldots \ldots \ldots \ldots$

5.3.4 Appropriate Methods for Encouraging the Adoption of Codes $\ldots \ldots \ldots \ldots \ldots \ldots \ldots .4$

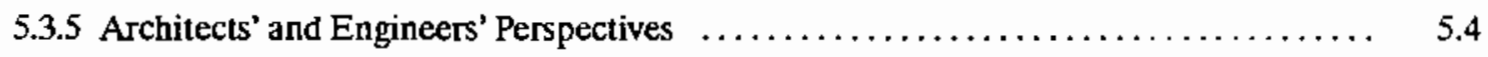

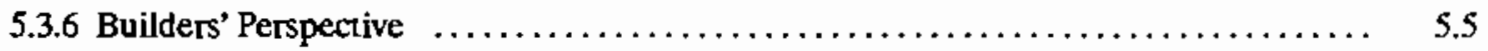

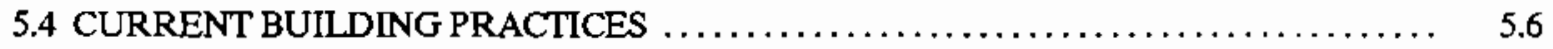

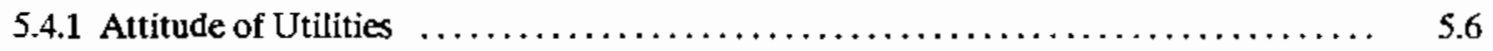

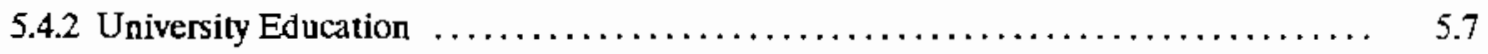

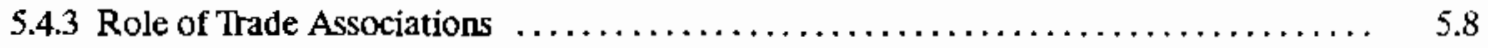

6.0 THE POTENTIAL FOR CODE UPGRADES OR ADOPTION OF ASHRAE/DOE

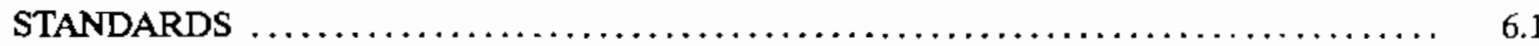

6.1 NEW MEXICO: POTENTIAL FOR CODE UPGRADE OR ADOPTION OF

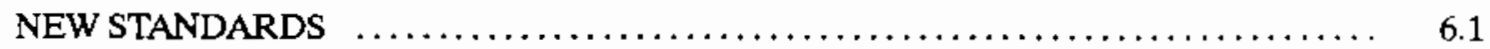

6.1.1 Prevailing Attitudes about Building Energy Conservation $\ldots \ldots \ldots \ldots \ldots \ldots \ldots \ldots .1$

6.1 .2 Adoption of the New Standards $\ldots \ldots \ldots \ldots \ldots \ldots \ldots \ldots \ldots \ldots \ldots \ldots \ldots \ldots \ldots \ldots \ldots \ldots, \quad 6.2$

6.2 ARIZONA: THE POTENTIAL FOR CODE UPGRADE OR ADOPTION OF THE

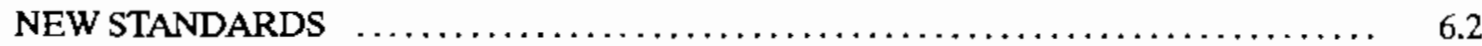

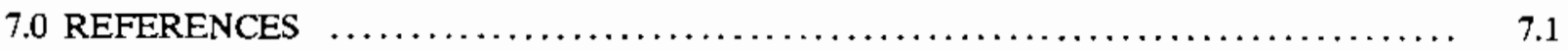

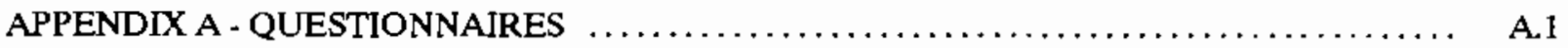

APPENDIX B - PASSING WITH A "D" IS FAILURE $\ldots \ldots \ldots \ldots \ldots \ldots \ldots \ldots \ldots \ldots \ldots \ldots \ldots \ldots \ldots \ldots \ldots$ 



\subsection{INTRODUCTION}

Over the past decade, the U.S. Department of Energy (DOE) has developed a series of performance standards to improve the energy efficiency of residential and commercial buildings in the United States. These standards were developed in respouse to the Energy Conservation Standards for New Buildings Act of 1976 (42 U.S.C. 6831 et seq.), as amended. The standards provide energy performance requirements that are mandatory for federal buildings and voluntary for private sector buildings.

The DOE is now considering ways to encourage formal adoption at the state and local level of the codified versions of the standards.

Pacific Northwest Laboratory ${ }^{(\mathrm{a})}$ has conducted this study to assist the DOE in understanding the processes by which energy codes have been adopted, upgraded and implemented at the state and local levels. This understanding will be critical to DOE's efforts to shape policies, programs and otherwise effectively support the acceptance and diffusion of the new energy standards. This study presents a comparison of the processes by which energy codes for commercial buildings were adopted and implemented in New Mexico and Arizona.

At the present time, all states have building energy codes or guidelines. These codes are mandatory in $\mathbf{3 4}$ states, voluntary in 16. The various state codes are diverse in their coverage, stringency, and sophistication. The diversity of content and application of state energy codes is, to some extent, mirrored in the variety of processes the states have used to adopt and upgrade their codes.

This case study does not attempt to describe a generic set of processes or energy code issues, but

(a) Pacitic Northwest Laboratory is operated for the U.S. Deparment of Energy by Battelle Menorial Institute under Contract DE-AC06-76RLO 1830. only to articulate those relevant to the states of New Mexico and Arizona. In addition, the study focused only on commercial building codes, which are generally more complex than codes promulgated for residential structures (although certain adoption issues are common to both types of codes). Until other state processes are studied, the extent of the similarities and dissimilarities to the situation in New Mexico and Arizona are unknown. Nevertheless, it is expected that a more extensive study would show that at least some elements of the two states' experience have been paralleled in other parts of the country.

\subsection{BACKGROUND}

Efforts to mandate or recommend levels of building energy efficiency began in the mid-1970s in response to the 1973 energy crisis. At that time, several "model" energy codes (MECs) and standards were created by national organizations; for example, the American Society of Heating, Refrigerating and Air-Conditioning Engineers (ASHRAE) and the Council of American Building Officials (CABO).

These standards and codes were subsequently adopted by many states, usually as an appendix to their Uniform Building Code (UBC) regulations. As noted above, in some states the energy codes are mandatory energy performance levels, in others, voluntary.

Other states (such as California, Florida, and, more recently, Washington, Oregon, Alaska and New York) have developed tailored state codes that depart from the MECs developed by organizations such as $\mathrm{CABO}$.

Since the 1970 s, many states have continued to improve and upgrade their building energy codes, 
often by adopting upgraded versions of the national model codes. ${ }^{(a)}$ Other states have retained their original energy code.

Although widespread in state building regulations in the United States, building energy codes have been controversial. In addition, building energy performance has not been universally accepted as a matter for state or local regulation. As a result, the process of adopting and upgrading energy codes has often been highly politicized. The processes of adoption, implementation and compliance at both the state and local level have had significant effects on the technjcal content of codes and the degree to which they result in more efficient buildings. This study sought to examine these processes and the issues that surround them in two southwestern states.

\subsection{ORGANIZATION OF THE REPORT}

The remainder of the report is divided into five chapters. Chapter 2 contains the study's conclusions, as well as some recommendations and suggested strategies for DOE to promote its standards. Chapter 3 provides a short discussion of the approach and methodology used to obtain information about each state's energy code situation and processes. Chapter 4 provides details about research findings in New Mexico, while Chapter 5 describes those from Arizona. In Chapter 6, the likelihood that either state will move to adopt the code version of the new performance standards for commercial buildings and the type of DOE support that would facilitate such action are discussed. Appendix A contains a complete set of the questions that served as guidelines for telephone interviews with interviewees in both states. Appendix B contains an article describing problems inherent to the Model Energy Code in trying to achieve energy efficient building construction. (a) Typically, the national code development organizations review and upgrade MECs (and other building codes) every three years. 


\subsection{CONCLUSIONS, RECOMMENDATIONS.AND STRATEGIES}

This chapter presents conclusions about energy code adoption and process issues in New Mexico and Arizona. Following these concluding remarks about the status of energy codes in the two states, interviewees' comments about DOE's potential role in promoting the adoption and implementation of its new standards are presented and discussed.

\section{I CONCLUSIONS ABOUT COMMERCIAL ENERGY CODES IN NEW MEXICO}

The following brief comments sum up PNL's findings on energy codes in New Mexico.

- Mandatory state-wide energy codes are wellestablished in New Mexico

On the whole, New Mexico's current commercial energy codes seem to be well-accepted and well-implemented throughout the state and, in general, compliance difficulties that occur during design and/or construction seem to get resolved with the assistance of local and state code officials.

- The current energy and building climate in New Mexico may make it dificult to adopt the DOE or ASHRAE standard in the near future

There is some question whether the current code could be easily replaced by a significantly different code or standard. Interviewees gave several reasons: the new standards are complex and differ substantially from the existing codes in basis and coverage (including innovative building technologies and equipment); the new codes may require significant alterations in current building practices; and New Mexico has established the MEC and its revisions as the source of the state code. Traditionally, the electrical (lighting) portions of model codes have been omitted when the state revises its codes. Altering this tradition through a revised code may be particularly difficult.
Possible sources of difficulties couid include the prevailing attitudes about building energy conservation; the sluggish state of the construction industry, the state's energy supply surplus; and the desire of at least some contractors, building designers and code officials for more (not less) prescriptive requirements.

- While training efforts and application guides provided by the state have been quite helpful, the need for training is ongoing. Outreach efforts should target contractors and building designers.

Although most code officials contacted by PNL had attended the state's workshops in 1988 and found them useful, there was some indication that more training (perhaps at a higher level) would also be appreciated. None of the A\&E firms or contractors PNL contacted had attended the workshops. According to attendance records, a number of firms did attend. While the firms PNL contacted felt that compliance with the energy code was not problematic, several interviewees identified areas where clarification in interpretation would be welcome. Several interviewees stressed the importance of education and ongoing dialogue between the state and the building community in implementing energy codes and improving the energy efficiency of buildings.

- The code supports design flexibility, but these same features also contribute to occasional compliance misunderstandings during design and/or construction of commercial buildings. These misunderstandings reduce the eltectiveness of the code.

Most of the interviewees at the local level (A\&Es, builders, and code officials) had at least one example of difficulty in achieving the correct compliance level in design or construction. The examples dealt with construction problcms in attempting 
to comply with the code, with determining acceptable tradeoffs between component conservation measures or correct levels when non-depletable energy sources were involved, and with the use of the systems analysis approach.

Although many interviewees voiced a desire for codes that are easier to comply with (i.e., more prescriptive), the trend in energy codes has been to increase the flexibility, not to decrease it. At the same time, the disadvantage of prescriptive or prescriptively interpreted performance codes (see the paper included as Appendix $B$ ) is that they result in buildings that "just meet" the code.

Although these conclusions reflect the situation in New Mexico, it is likely that the issues they represent are repeated in many other states as well.

\subsection{CONCLUSIONS ABOUT COMMERCIAL ENERGY CODES IN ARIZONA}

Arizona, which has taken a less traditional approach to building energy efficiency than New Mexico, offers additional lessons that have application to other states where energy codes have had little impact. These conclusions are provided below.

Adoption of a coinmercial building energy code will be difficult in Arizona for the following reasons:

\section{- Previous experience with previous code adoption.}

Because of the negative experience and undesirable results from the previous energy code adoption efforts, the AEO, which would be the most logical agency for initiating a code, is not likely to resume the process. In fact, AEO staff have stated that they would be unwilling to initiate the process for several years. Before the effort could be successful, the local autonomy and cost issues would need to be resolved.

\section{- Dissatisfaction with the ASHRAE standard}

Several interviewees mentioned that the ASHRAE standard is oriented toward the heating season rather than the cooling season. This perception could stall efforts to get the ASHRAE or DOE standard adopted in the state. Although the state has quite a diverse climate, overall energy loss during the cooling process is most prominent.

\section{- Substantial educational efforts required}

To get the state to "buy into" the idea of an energy code, substantial educational efforts directed towards several target audiences would be required. Architects and engineers, builders, city officials, legislators, and the public would have to be educated.

Moreover, each of the target groups would require different orientations. The architects would need to be educated on design methods matching energy conservation features with aesthetics; builders would need information on the costs of various features of the code and on installation methods; city officials would need to be taught how to inspect the features both on the plan and in the building; legislators and the public would need to be educated on the advantages of energy conservation. Education will be the key method for encouraging the adoption and implementation of an energy code.

\subsection{RECOMMENDATIONS AND STRATEGIES}

This final segment provides a summary of the in. terviewees' comments regarding potential DOE roles to encourage the adoption and implementation of the new energy standards for commercial buildings. The recommendations also reflect PNL's findings about the non-code mechanisms that have influenced the construction of energy-efficient buildings. 
2.3.1 Potential DOE Roles to Encourage Adoption of the New DOE/ASHRAE Commercial Standards

The discussions held with interviewees about adoption of the new standards provided a number of useful insights and suggestions about DOE's potential role. These have been summarized below.

\section{- Conduct a substantial information campaign on the new standards}

Simply to make the building community and state and local code officials aware of the existence of its commercial building energy standard, DOE may need to launch a publicity campaign of sorts, hold workshops, etc. Although interviewees were generally aware of the development of ASHRAE 90.1, most were not at all aware that, as a result of national legislation, DOE had begun a parallel standards development. Only one interviewee was aware that the new standards are software-based or that they represent a new generation in energy standards.

\section{- Bridge the gap between the new standards' for- mat and content and that typically found in building codes}

Most interviewees believed that the new standards would be most acceptable to states if somehow codified in a manner similar to existing model energy codes such as the MEC. Several interviewees stressed the need for the new standards to "fit into" a familiar mold, even though they represent a significant departure from current energy codes. Interviewees suggested DOE could best ac. complish this by working with the various code development organizations such as $\mathrm{CABO}$.

Adopting the standards by reference has been suggested as an alternative to codification. However, comments on ASHRAE 90.1 (its length, wordiness, relative complexity, difference from existing codes in approach, etc.) imply that this strategy may not be well-accepted at the state and local level.
The following suggestions have been included in this section because, although they pertain more to implementation concerns, they are also likely to affect the adoptability of the new standards.

- Develop reliable and easy-to-use implementation tools to support the new standards

Even after being in use for over a decade, the relatively straightforward nomographs and conservation measure tradeoffs in the MEC occasionally cause confusion and compliance problems for designers, builders, and code officials in New Mexico. The complexity and increased flexibility of the new standards are likely to increase the difficulty of applying them; thus, there may be resistance to adoption unless accompanied by easy-to-use tools to interpret requirements at the local level.

Without such tools, states may refuse to adopt the new standards without adding restrictions; for example, by establishing a limited number of climate zones and minimum requirement levels.

\section{- Develop simplified processes for determining compliance to support the new standards}

While determining and enforcing compliance in residential and simple commercial structures can be relatively easy for code officials, doing so for complex commercial buildings is ofien much more difficult and time-consuming. DOE could support the development of processes to facilitate enforcement. For example, one interviewee suggested that tools to digitize blueprint information (e.g., opaque wall area) and to automate verification that designers have made component tradeoffs correctly would do much to lower code officials' resistance to the new standards. However, such tools are likely to require the use of computers, which code jurisdictions generally do not use except to manage data. Thus, DOE may also need to subsidize local jurisdictions both to acquire adequate computer equipment and to train code officials in the use of such tools. 
- Verify the energy savings or buildings constructed to level of the new standards and reassure the building community that the standards can be met using familiar techniques.

At least a portion of the building trades community is likely to resist the new standards initially because of issues such as the need to change from $2 \times 4$ to $2 \times 6$ inch framing members, different roof truss systems, new insulation techniques, lighting designs and/or relatively uncommon types of glazing. Therefore, there will be a premium on proving that the standards can be met using familiar techniques and materials, as well as on educating builders and subcontractors in the use of new, more efficient approaches.

\subsubsection{DOE's Role in Assisting Implementation of Upgraded Codes}

PNL asked interviewees to comment on the potential value of several options that DOE could use to help states implement the new standards, once they are adopted. These comments are sum. marized below by option.

\section{- Conduct demonstrations of specific technologies}

The interviewees responded that, in general, demonstrations are only marginally helpful. "It depends on what you demonstrate and for whom ${ }^{n}$... "demonstrations work only if you get the information to the right people, at the local level, and this usually doesn't happen." Staff from ECMD indicated that New Mexico is already conducting technology demonstrations (funded by oil overcharge funds) and that additional ones are not really needed.

- Hold design competitions (for innovative energy-efficient commercial structures)

One interviewee commented that design competitions (and technology demonstrations) might be somewhat helpful. The remaining interviewees indicated that this approach is not helpful, primarily because $A \& E$ firms are not interested in participating.

\section{- Provide technical/design assistance}

Views on this option varied from those who felt it might be quite helpful, if provided in an accessible manner (e.g., regional technology transfer and assistance centers), to fairly negative views. "Some of this can be helpful, but it can also be disruptive to the design process. It would be more helpful in the context of education, not assistance after or during the design process." "This is probably an OK idea, but DOE has to get technical assistance provided to it before it can go out and give it to the building community. This is not a Ph.D. level activity...while there has to be a certain amount of 'toploading' (high-level technical expenise), there also has to be a certain amount of 'bottom-loading expertise' from builders, designers and inspectors. The worse thing is to hand down advice and requirements from the top."

\section{- Develop computer-based compliance and design} tools for users and enforcement officials

The consensus was that this option would be helpful, although "the tools would have to be very user-friendly, because you are not going to find highly technical staff in many county or city code offices." "Computer tools might help, but it would take a fairly large and busy building department to use them." "There is a lot of desire on the part of engineers to use a comprehensive approach to energy-related design, but it still comes down to the economic issues--what the features cost, and whether the owner is willing to pay for them."

\section{- Develop and support training and education programs}

Interviewees viewed this option as very important ("essential," "extremely important") for implementation of better codes. "The state and local offices just don't have the money." "We just couldn't do it; this is an ongoing problem." One interviewce noted that the training programs would "have to be very tailored to local needs and problems and directed at the right people, i.e., the builders, designers and code inspectors." Education programs (offered at vocation-technical schools and in architecture 
and engineering curricula) were also viewed as critical for longer-term improvements in the design and construction of energy-efficient buildings.

\subsubsection{DOE's Potential Role in Supporting Enforcement}

\section{- Provide training for building code officials}

To ensure that the codes are attaining their goal of energy conservation, a strict enforcement mechanism will need to be put in place. According to the New Mexico building code officials, compliance with the code is primarily due to strict and consistent enforcement practices. All officials agreed that having a reputation for not letting infractions slip through the inspection considerably eased their enforcement responsibilities.
- Coordinate efforts with utilities' demand-side management programs

Building energy codes attempt to achieve the same goals as those of demand-side management programs. Both improve and encourage energy efficiency, reduce load growth uncertainty, reduce damages to the environment, and suppori continued economic growth. Moreover, both are implemented through similar channels, such as technical assistance, education, and information dissemination; and both require an understanding of the needs of similar audiences. Because of the similarities, utilities and energy policy makers can use the information leamed from the code adoption and implementation processes to improve their demand-side management programs. Conversely, those involved in the code adoption process can learn from the experience of demand-side management programs. 



\subsection{APPROACH AND METHODOLOGY}

Arizona and New Mexico were selected for this case study because energy codes in these two states have evolved differently over the past thirteen years. For example, New Mexico's energy code is mandatory for residential and commercial buildings in both the public and private sectors. The code was upgraded twice (in 1980 and 1986) to the thencurrent version of the MEC.

In contrast, the Arizona energy code, which is a version of the original MEC, is mandatory for stateowned buildings, but only a recommended energy efficiency guideline for residential and private commercial buildings. Although they may do so, none of Arizona's municipalities and code jurisdictions have adopted the Guidelines as a code. Furthermore, Arizona has never upgraded the energy performance levels in its original guidance, nor made them mandatory for non-government construction.

In spite of their different response to mandatory building energy efficiency, New Mexico and Arizona share many similar features--a dry, sunny climate with a fairly wide range of heating and cooling demands; building styles; energy costs; and general construction trends.

This study explores some of the reasons for the differing response in the two states over the past thirteen years, as well as the likelihood for the new standards to be accepted there.

\subsection{DATA COLLECTION}

Very little written information is available on energy codes in either of the two states selected for the study. Therefore, PNL conducted semistructured telephone interviews to obtain information on the political/regulatory process associated with code adoption, on code implementation and compliance issues, and on energy-related building practices.
In most cases, the interviews were guided by scyeral prepared sels of questions (or protocols) designed to elicit the interviewees' views on specific aspects of energy codes for commercial buildings.

\subsection{INTERVIEWEES}

The study focused not only on the adoption of commercial building energy codes, but also on their implementation and their impact on the building community. Accordingly, PNL sought the views of a broad range of individuals, including state employees, city building officials, architects and engineers, builders, and utility staff.

State employees were selected based on their involvement with either the state building code process or the state energy office. Building code officials from most of the larger communities in both states were contacted. Because Arizona does not enforce an energy code, relatively fewer officials in that state participated in the interviews. Architects, engineers and builders were selected both randomly and as a result of referrals. Staff from the principal utilities in each state were also contacted. Typically, these individuals were involved with the utility's current energy conservation programs.

\subsection{INTERVIEW QUESTIONS}

Several sets of questions were prepared to guide the interviews over a range of issues. PNL used three separate protocols, one for each key area of interest: adoption, implementation, and compliance. Appendix A contains a complete set of these questions.

In most cases, the questions provided structure to the interviews and ensured consistent acquisition of information on certain key issues. Howcver, interviewees were cncouraged to expand on a topic, to provide specific examples, and to discuss related matters as well. 
Because of the status of energy codes in Arizona, the prepared questions proved less useful and appropriate there than in New Mexico. Therefore, the Arizona interviews relied less on the protocols and were much less structured than those in
New Mexico. At times, the interviews were simply discussions of the interviewee's general views on commercial building energy consumption and the use of codes versus other means to attain adequate levels of performance. 


\subsection{ADOPTION AND IMPLEMENTATION OF COMMERCIAL ENERGY CODES IN NEW MEXICO}

Findings from the New Mexico interviews are presented below. In general, the findings have been organized by perspective and key focus area.

\subsection{CURRENT STATUS OF COMMERCIAL ENERGY CODES IN NEW MEXICO}

As indicated above, New Mexico has enforced a mandatory building energy code for all residential and commercial construction since 1977. The code adopted by New Mexico was Appendix Chapter $\$ 3$ (Energy Conservation) of CABO's Uniform Building Code. This code, known as the Model Energy Code or MEC, was developed by CABO as the codification of the requirements of the ASHRAE's component energy performance standards (ASHRAE 90-75). By law, cities and other code jurisdictions in New Mexico can modify the energy code, but only by increasing the stringency of its requirements. To date, no code jurisdiction has sought to make any changes.

\subsubsection{Code Updates and Changes}

The state has upgraded its code twice to reflect the corresponding changes in the ASHRAE standard and the CABO code. The first upgrade occurred in 1980, when New Mexico adopted the 1979 edition of the UBC. While the energy code appendix of that edition still rellected the basic re. quirements of ASHRAE 90-75, the new model code contained some procedural changes (in particular, "Design by Acceptable Practice," Section 6) and, in its electrical section, the determination of illumination levels and a lighting power budget for all commercial structures.

As will be discussed in the section on the code adoption process, the lighting power budget proved to be highly controversial in New Mexico. As a result, the 1980 version of New Mexico's energy code excluded the MEC's lighting budget requirements (Sections 505 and 605).

The state code was updated again in 1988 to reflect the provisions of the $1986 \mathrm{MEC}$, which incorporated the requirements of the ASHRAE 90A-80 standard. The $1986 \mathrm{MEC}$ requirements for the design of electrical power and lighting systems were again specifically deleted from the state code.

New Mexico made one other major change in its upgrades of the MEC. Based on building energy use research at the University of New Mexico, the state created a means of accounting for the effect of certain local building materials and techniques (e.g., adobe walls and passive solar construction) on the heating and cooling load of buildings in $\mathrm{New}$ Mexico's climate. This modification, called Effective U-Values, was added to both the 1980 and the 1988 updates. It gives greater credit to thermal mass and passive solar features, such as south. facing fenestration and trombe walls, in certain heat-loss calculations required to show compliance. The 1988 code (1986 MEC) is still in force in New Mexico. Although the $\mathrm{MEC}$ itself was again amended in 1988 to make certain adjustments, New Mexico did not adopt these changes. ${ }^{(a)}$

\subsubsection{Code Compliance}

Compliance with the New Mexico energy code can be demonstrated in three different ways: 1) systems analysis and/or use of nondepletable energy sources, which allows designers to use a systems (whole building) approach or to incorporate the use of solar, wind or geothermal energy; 2) component performance approach, whereby each separate component meets certain efficiency requirements; and 3) acceptable practice, which allows for the construction of small, relatively simple buildings

(a) The thermat mass in U-value calculations was changed; U-yalues for composite wall materials were added; and certain nomographs for building component $U$-values were revised. 
using specified standard construction details and meeting door and window area limitations.

The rules and regulations specifying code requirements are promulgated by the Construction Industries Division (CID) of the New Mexico Regulations and Licensing Deparment. In unincorporated parts of the state and for all public buildings, inspectors from the CID are responsible for determining compliance; otherwise, municipal inspectors enforce the code.

\subsection{ENERGY CODE ADOPTION AND CODE ADOPTION ISSUES IN NEW MEXICO}

Information about New Mexico's code adoption and update processes, and relevant issues are discussed below.

\subsubsection{The Building Code Adoption Process}

In New Mexico, the adoption and modification of building codes is carried out by the Construction Industries Commissioner and Board, who are appointed by the Governor. The adoption/ modification process generally occurs on a threeyear cycle (reflecting the code update cycle of $\mathrm{CABO}$ ) and has several distinct stages.

When a code update or adoption process is initiated, the Commissioner appoints a Technical Committee, typically composed of architects, engineers, building contractors, relevant state and city staff, and others as appropriate.

The Technical Committee meets several times to consider the proposed code or code changes, which primarily come from $\mathrm{CABO}$ and other similar organizations. In the case of energy codes, the introduction of state-developed modifications has been fairly common, however.

The Committee then presents a recommendation to the Commissioner and Board for review. If no additional modifications are made, the proposed code is presented at public hearings across the state, after which the Technical Committee again reviews the code to make any necessary changes or recommendations. Finally, the code is presented to the Commissioner and the Board of Construction Industries for adoption.

If approved, the code is sent to the state archives and generally goes into force 30 days later. The state often holds educational or training workshops in conjunction with this process to communicate the proposed changes to the building community and to build support. In general, the adoption of and revisions to New Mexico's energy code have followed these steps.

\subsubsection{Energy Code Adoplion Participants}

Several groups have been actively involved in these processes: staff from the state energy office (the Energy Conservation and Management Division of the New Mexico Energy, Minerals and Natural Resources Department) and from the CID; the architect and building engineering community; and certain city building officials (particularly an individual from the City of Albuquerque who serves on the CABO Energy Committee and staff from the City of Santa Fe).

Individual builders and contractors, as well as the state chapter of the National Homebuilders Association, were somewhat involved, principally during early meetings of the Technical Committee. However, several interviewees commented that builders and contractor groups who were given the opportunity to participate in the review process and declined to do so became more active and adversarial during the public hearings and Commission sessions. Representatives of energy-related construction materials also attended and presented testimony during the Technical Committee's code review sessions. During the initial adoption, staff from state agencies representing the handicapped and historical building groups attended Technical Committee sessions to ensure that the energy code did not adversely affect these interests.

There was very little participation in either the adoption or revision processes by consumer groups, environmental groups, state legislators, rcaltor 
groups, or the principal utilities in the state. City code officials, as a group, did not participate.

One of the questions in the protocol on code adoption asked interviewees whether other groups should be involved in future energy code revisions. Several interviewees felt that more involvement should be sought from the utilities, from the state Consulting Engineers Council [and local ASHRAE and Illuminating Engineer Society (IES) chapters], from property management associations, and consumers. In addition, these interviewees felt that builders should be more proactively included in the development/initial review stage of energy code upgrades.

\subsubsection{Code Adoption Issues}

In the evolution of New Mexico's energy code, the most controversial issues were the lighting power budget and illumination level requirements stipulated by the $1980 \mathrm{MEC}$ and subsequent revisions, thermal mass/passive solar concerns, and requiremen ss to insulate slab-on-grade foundations. These issues are discussed below.

When the Technical Committee initially considered the $1980 \mathrm{MEC}$ revision with the added lighting power budget, it recommended that this feature be included because of the extent to which lighting energy can dominate the energy consumption in certain commercial buildings. ${ }^{\text {(a) }}$ However, electrical engineers and the local chapters of the IES strenuously opposed this requirement later.

Interviewees who commented on this opposition attributed it to three possible causes: 1) the economic impact on the consulting fees of lighting engineers, i.e., fewer lighting fixtures meant lower fees; 2 ) the difficulty of substantiating additional consulting fees for the extra work involved in designing lighting that complied with MEC requirements; and 3) concern that the proposed lighting

(a) Lighting energy can constitute from 30 to 50 percent of total building energy in commercial structures; heat transfer from lighting also can significantly increase a bujiding's cooling requirements (NM 1988). power limits conflicted with illumination standards requirements for minimal illumination levels in commercial buildings.

The IES opposition was applied most forcefully during the deliberations of the Commission on the code recommended by the Technical Committee. In particular, interviewees stated that the Commissioner himself was lobbied quite heavily to exclude the lighting portion. When the Board adopted the 1980 update, all lighting power and illumination level requirements in the revised MEC were omitted and have never been adopted.

A second issue that arose during the first code revision related to architecis' and builders' concerns over the disadvantage placed on the use of passive solar features and adobe walls in the original MEC. These concerns were widespread within the building community, and the Technical Committee dealt with the issue by adding the section, Effective $U$ Values, noted above.

The third issue that came to light in the interviews was perimeter insulation, particularly of foundation slabs. Opposition to the requirements for slab insulation stemmed primarily from builders' unfamiliarity with the construction techniques needed to insulate this type of foundation to coderequired levels. The problems were somewhat resolved when the CID, city code officials, architects, and builders worked together to determine acceptable design and construction techniques. ${ }^{(b)}$

\subsection{CODE IMPLEMENTATION: STATE PERSPECTIVES}

A series of questions asked about the state role in implementation of energy codes. These questions were focused on 1) New Mexico's efforts to inform members of the building community and code officials about the code (and code revisions); 2) the

(b) However, certain techrical construction problems still persist with slab insulation; see comments in the paper provided in Appendix B, "Passing with a ' $D$ ' is Failure", by K. Scheuch and R. Busch. 
training provided by the state to ensure adequate compliance and enforcement; and 3) code-related administrative impacts.

\subsubsection{Information Dissemination and Training}

Information about the newly adopted code and subsequent revisions was disseminated by the state through various newsletters (for building professionals, builders' associations, etc.) and through direct contacts with members of the same associations (presentations at meetings). The state also sponsored workshops on two occasions (1978 and 1988) for architects and engineers, builders, and code officials to provide training on the requirements of and compliance approaches to meet the new code. In both instances, these workshops were conducted before the new code was implemented.

Finally, the state developed an applications manual for building designers, construction contractors and code officials. The manual laid out background information, code compliance procedures, and examples of compliance calculations. The manual was substantially revised in 1988 to improve its usefulness and was used as the basis for the state's training workshops held that year.

\subsubsection{Administrative Impacts of Adoption and Implementation}

Code adoption and implementation had definite but not unmanageable impacts on both the Division of Energy Conservation and Management (ECMD) and the CID. For the former, the chief cost was the staff time to suppor the review and modification of the MEC (estimated to be $1 / 4$ man-year for three years during the latest revision). In addition, the ECMD provided $\$ 50,000$ to fund studies on the impact of the code revisions and to adapt the MEC to allow credit for thermal mass in walls. Finally, the state used oil overcharge money to update the applications manual and to fund its 1988 training sessions. For the CID, the principal cost was for staff time to educate people who did not attend the state's training workshops; this cost, however, was considered to be par of the CID's normal responsibilities.

\subsection{CODE IMPLEMENTATION: CITY PERSPECTIVES}

A number of city code officials were contacted to obtain their views on topics such as general training requirements and staffing levels; plan review; site inspection; energy code training; adequacy of resources to enforce codes; and builders', architects; and engineers' general level of understanding of energy code requirements.

Code enforcement officials in six of New Mexico's larger communities were contacted. Commercial building activity in these communities has ranged from about 15 (Taos) to over 800 (Albuquerque) building permits per year in recent years. Office and retail structures have dominated recent new construction in these areas.

\subsubsection{Training and Staffing}

State law requires building code enforcement officials to have both certification and a considerable amount of construction experience. Several of the officials PNL contacted had one or more engineering degrees, and more than one office also had an architect on its staff. The officials PNL interviewed averaged 12 years of experience enforcing building codes. Staffing levels ranged from one-person offices in the smaller communities to offices with over 30 employees.

\subsubsection{Plan Review and Site Inspections}

The interviewees indicated that inspectors generally do not view one aspect of the energy code as more important than another: "All parts integrate to make one complete code." Envelope insulation requirements seem to cause somewhat more questions and review problems than the mechanical portion of the code (which covers sizing and efficiency of mechanical equipment): "Contractors do not know how to interpret the code in this area [insulation]; most people don't know the state puts out an interpretation manual."

Similarly, site inspections most often reveal that contractors have problems with installing insulation 
and achieving the required levels. In general, "compliance is good because the contractors know that they won't receive a certificate of occupancy if they don't comply with the code." (None of the interviewees could recall with holding a certificate of occupancy for energy code non-compliance: "Compliance problems are taken care of before the completion of the project."

\section{4,4.3 Energy Code Training and Enforcement Resources}

All interviewees mentioned the energy code training provided by the state, which appears to have provided a good basic understanding of the code, building energy issues, and the most common compliance approaches. One office also mentioned that the newsletters ECMD issues occasionally are helpful. However, most of the interviewees indicated that additional (and more frequent) training and support by the state would be helpful, particularly in the areas of consistent interpretation of insulation requirements, on code revisions, and on documentation of the types of typical construction practices that meet envelope requirements (to make enforcement easier). There was some indication that the complexity of commercial structure insulation requirements has led to "in-house" interpretations of the code to try to provide locally consistent enforcement.

When asked about resources ${ }^{(a)}$ needed to adequately enforce the commercial energy code, the interviewees provided mixed responses, reflecting the varying size and level of activity of each office. Training was mentioned somewhat more frequently than the other items as a needed resource. One office also expressed a need for more staff, and another for more sophisticated equipment to improve its ability to do structural analyses of plans.

(a) "Resources" inciuded funding, staft, training, equipment and "olher" (resources specitied by the interviewer).

\subsubsection{Levels of Understanding of Energy Code Requirements}

Responses were mixed to PNL's inquiry about the degree to which contractors and designers understand New Mexico's energy code requirements. In New Mexico's largest cities, the building community appears to have developed a good understanding of the design and construction requirements of the code. In smaller communities, code officials get "a lot of questions"; although most of the time, the requirements can be explained fairly easily--for example, how to use the tables in the code. One official expressed a desire for the state to conduct more seminars for contractors.

In conclusion, the code officials PNL contacted appear to have relatively few problems enforcing the current energy code, perhaps because of the length of time it has been in place with relatively consistent requirements. Most of the interviewees had few suggestions for improving the code, other than to provide the building community with more prescriptive guidance on compliance. One official expressed a desire to add lighting power requirements to the code and to move the state code closer to the current ASHRAE standard.

\subsection{CODE COMPLIANCE: VIEWS OF ARCHITECTS AND ENGINEERS}

The questions for these interviewees centered on compliance with the New Mexico energy code in both the design and construction phases of a project. PNL also discussed the types of requirements emphasized in enforcement; the issue of training on code requirements; and the interviewees' perception of the adequacy of code officials' knowledge about the code.

\subsubsection{Code Compliance During Design and Construction}

As was the case with code officials, architects and engineers tended to view the energy code as a composite, inter-related set of requirements and, for the most part, did not initially distinguish one 
part of the code or another as difficult or easy to comply with at the design stage. However, some indicated that problems sometimes occur during construction when the contractor attempts to meet the roof and wall insulation requirements as designed by the architect or engineer. One engineering firm also implied that the code was difficult to comply with when large amounts of glass are used as envelope material (mirror glass is an increasingly popular envelope material for certain types of commercial construction in New Mexico).

Most of the interviewees indicated that their firms generally design buildings that somewhat exceed minimum code requirements. One engineer stated, however, that "commercial clients will often try to get away with as low a level of compliance as possible" or that the components as designed may be in compliance, but "a lot of times the owner won't pay to comply to code, so the workmanship is cheap" (i.e., costs ate cut on installation, possibly diminishing the intended energy efficiency).

\subsubsection{Enforcement}

Interviewees were asked questions about enforcement to determine whether all aspects of the code tend to be enforced equally. The indications are that insulation requirements tend to be enforced most rigorously by code officials and that compliance problems were ofien found with roof insulation, typically because of improper installa. tion. One interviewee commented that code officials enforce the insulation requirements most vigorously and the mechanical (heating, ventilating and air-conditioning) equipment requirements least strenuously. He added, "This is odd, since the insulation requirements are the most expensive part of the code (in terms of Btu savings per cost of component compliance) and the HVAC are the cheapest."

These comments about the parts of the code most emphasized in enforcement corroborate those made by several of the code officials.

\subsection{Energy Code Training}

None of the A\&E firms PNL contacted had staff who had received formal training on compliance with the state energy code. However, most interviewees generally did not perceive this to be a significant problem. Compliance requirements and approaches tended to be learned somewhat informally, through review of technical journals and the code application manuals, in-house discussions, and by contacting local code officials. When asked about improved or additional training, however, about half of the interviewees offered suggestions ranging from better definition of the code requirements (less ambiguity) to thorough training on the entire code (paid for by their own firms).

When asked whether code officials seem to be adequately trained, all interviewees responded that local officials had adequate knowledge of the energy code and were able to answer any compliancerelated questions. One interviewee commented that staff at CID nay need better training in energy code compliance to improve consistency of responses.

\subsection{CODE COMPLIANCE: VIEWS OF BULLDERS}

The New Mexico contractors encountered few problems with the energy code. However, it was quite clear that very few knew much about the codes. Most of the initial contacts referred PNL staff to some other company because they could not answer the basic question, "What problems do you encounter when complying with the commercial building energy code?" Quite a few of the general contractors referred us to their subcontractors, who also had little knowledge of the code. Almost all of the builders relied on the plans designed by architects and engineers.

\subsubsection{Compliance}

Overall, the building contractors claimed to have very few problems complying with the code. There 
seem to be two reasons for this assertion: 1) the builders rely on the design requirements specified by the architects and engineers, and 2) they have very limited knowledge of the energy code.

The contractors who seemed to have at least some knowledge of the energy code claimed they had no difficulty in complying with it. The code is "fair" and poses "no economic barriers" such as expensive equipment or materials. Also, it is very general in its specifications: R19 for the walls, R11-19 for the roof, etc. The lack of flexibility leaves no room for ambiguity, and the required equipment is readily available.

When asked what code requirements are most difficult to comply with, most said, "There really aren't any." The only aspect that poses any kind of problem is working with a lot of glass: "You have to be very careful" to get the correct amount of insulation. Somelimes double pane glass has to be obtained through the manufacturer (instead of the supplier). However, another contractor mentioned that complying with the code when using a lot of glass is not a problem: "It's no different" than constructing without a lot of glass. Basically, "it's easy to comply" with the code, and all said their company generally exceeded the minimum commercial building energy codes.

The contractors who had limited knowledge of the code were those who install the equipment and provide labor, rather than the general contractor. According to one construction company employee, "New Mexico does not have any code on insulation .... An individual can choose" the level of insulation, whether it be R-3 to R-38 or no insulation. "It's the owner's preference." He did admit, however, that he was "not familiar with the code." Another claimed New Mexico had no codes for commercial buildings. He "goes by the architectural plans." He also said "there is no standard for the efficiency of equipment." When asked if they compare initial costs with operating costs, he said they compare the costs "for quite a few" buildings. Usually, however, "whatever equipment we can afford" is used.
Regardless of their knowledge of the code, all felt their buildings complied with it. Most assumed the code follows standard building practices.

\subsubsection{Building Officials' Knowledge}

According to one general contractor, building officials generally look at the energy calculation that the contractor computes. The building official does not enforce any one area more rigorously than another. "It's pretty cut and dried." He felt local building officials have adequate knowledge of commercial building energy codes. Another felt the "building officials depend heavily on energy requirements provided by engineers."

\subsubsection{Training}

None of the companies contacted had any formal training specific to the code. They learned of the code informally through experience with the codes. One general contractor commented that training courses have been offered since the code first came out in 1977, but neither he nor his staff attend them. "There's not much there." The only thing of use is the energy calculations and they are "very, very straightforward." The only additional training that might be helpful is to review the code for an hour and study the methodology for the energy calculations, both of which can be done by the individual.

None of the contractors seemed to think the lack of training was a problem. The requirements for the building are specified on the plans, and the requirements "are pretty well spelled out." They "rely on the architects and engineers" to meet the code in their plans.

One contractor was much more aware of Califomia's code because "it's stricter." Code compliance is more involved because contractors have to submit energy analysis plans. They learn of California's requirements because someone sent them the manual. 


\subsubsection{Code Changes}

The contractor with the most knowledge about the codes claimed he would like to see a more stringent code since most of the buildings are currently being built to the code level. He would like to see particular attention paid to improved insulation in the walls. He definitely feels that the cost of operating the building should be compared with the initial cost of installing energy efficient equipment and materials. He also claimed that in New Mexico, "politics drive [the code]." He feels that getting more stringent codes adopted will require "more lobbying" and that the codes "need to be sold properly." Emphasis should definitely be placed on illustrating the reduced energy operating costs from more energy efficient construction. Giving tax credits for innovative design might be another way to "sell" the codes.

Most contractors did not have any suggestions for improving the codes. They felt they were stringent enough. One stated that he "would have to see the code first." Another admitted he was "not familiar with the code" and, therefore, could not recommend any changes to it.

\subsection{NON-CODE INFLUENCES ON ENERGY EFFICIENT BUILDING PRACTICES}

The major influences on energy efficient building practices in New Mexico have been local trends toward increased use of renewable resources and the diffusion of more efficient building practices and materials within the building trades. In commercial construction, these trends primarily take the form of greater use of passive solar designs, careful orientation of fenestration to improve daylighting in buildings and to reduce envelope heat loss, and a general movement toward the use of double glazed windows.

According to several interviewees, the latter trend has been primarily stimulated by consumer demand, supported by the decteasing availability of single glazed windows from building material suppliers. ${ }^{(a)}$

Unlike many large utilities in other parts of the country, New Mexico's major utilities have not developed strong programs to encourage construction of more energy efficient homes or commercial buildings. Most interviewees attributed this situation to excess power supplies, accompanied by lack of pressure from consumers, the legislature or the state utility commission.

(a) This trend is primarily found in residential construction, however. 


\subsection{ADOPTION AND IMPLEMENTATION OF COMMERCIAL ENERGY CODES IN ARIZONA}

Findings from interviews with key energy groups in Arizona are presented below. Like the discussion of the New Mexico interviews, the findings have been organized by perspective and key focus area.

\subsection{CURRENT STATUS OF COMMERCIAL ENERGY CODES IN ARIZONA}

In the early 1980 s, the Arizona Energy Office (AEO) unsuccessfully attempted to implement a state energy code for new buildings. According to one contact at the AEO, the AEO "did every thing right." They held public meetings, included many different groups in the process, and worked with builders on the technical aspects of the proposed code. Because of considerable opposition from local jurisdictions and home builder associations, however, the effort failed. Local jurisdictions opposed the idea of a state regulation that would stifle their autonomy in local matters, and the home builder associations resisted the perceived additional construction cost that the code would create. Because of strong resistance, the state legislature terminated the effort.

The code adoption process undertaken by the AEO lasted for about a year, culminating with an energy code for state buildings but not for private buildings. The proposed code was transformed into the Arizona Guidelines for new buildings; however, the Guidelines have not been updated since their development. Most of the respondents were not familiar with the Guidelines. Those who were claimed current building practices significantly exceed the stringency of the Guidelines.

\subsection{CODE UPDATES AND CHANGES}

Although no energy code has been established for private commercial buildings, a process exists for adopting a new code. According to NCSBCS (NCSBCS 1990), all types of codes in Arizona are changed according to the following schedule:

1. Staff in the Department of Building and Fire Safety review the code. The code is presented to the Department of Building and Fire Safety Board for review and action. The Rule Making Docket is opened.

2. The Rule is forwarded to the Attorney General's staff for informal review.

3. The Rule packet is prepared for submittal to the Governor's Regulatory Review Council for hearing.

4. The notice of Board hearings on the proposed rule is published in the Arizona Administrative Register.

5. The Board holds public hearing, votes to closc the record, and adopss the rule.

6. The Rule packet is forwarded to the Attorney General for certification ( 90 days allowed for this process).

7. The Attorney General certifies the rule and forwards it to the Office of the Secretary of State for filing. The Rule becomes effective when filed with the Secretary of State.

\subsection{POSSIBILITY OF CODE ADOPTION}

An energy code for commercial buildings is not likely to be adopted in the near future. State energy officials initiated efforts to adopt an energy code in the early $1980 \mathrm{~s}$. They are discouraged by the failurc of their attempt and currently have no plans for another try. Local officials interviewed generally supported the idea. There are scattered efforts at 
the local level to implement energy conservation measures but no initiatives for an energy code. Efforts to adopt a code at any level appear to be hampered by factors such as a surplus of power, high rate of vacancy in commercial buildings, and the relative low priority of energy conservation on the legislative agenda.

Builders and architects are ambivalent about an energy code. They recognize the value of energy conservation and, according to those interviewed, already include energy efficiency features in their buildings. On the other hand, they are not eager to have a code if it adds substantially to the time and cost of design and construction.

The perspective of each of the key groups is discussed in more detail below.

\subsubsection{State Perspective}

From the AEO's point of view, the adoption of a state energy code for commercial buildings is not likely to occur or even be initiated in the next several years. The AEO is reluctant to embark on this effort because of the level of effort required and the failure of the initial attempt.

Besides the past bad experience, other barriers preclude agencies within the state from taking action. First, Arizona has about $30 \%$ to $40 \%$ surplus power. During the summer of 1989, the three nuclear plants (Palo Verde 1,2, and 3 ) in the region were not operating, yet Arizona utiliuies easily satisfied the state's energy needs. Currently, the nuclear plants are on-line and generating power; Arizona is selling power to other states.

Second, the vacancy rate of commercial buildings is high (18\% to $20 \%)$, and the growth in new commercial building construction is low. The mid1980s saw profuse construction of commercial buildings. Consequently, most areas in Arizona were "over-built." As the supply of buildings outgrew the demand, the vacancy rates in these areas soared. Low construction activity precludes lawmakers from passing more stringent building codes: the legislature does not want to further burden a currently stagnate industry. The literature also supports this point.

Third, according to the AEO, "It is harder than the dickens to get the legislature to buy into energy conservation" However, because a number of incumbents in the Arizona state legislature are not seeking reelection, "there will be a whole new mix in the legislature" next year (1991). Therefore, it will be a "building block" year for the AEO, as they have to start from the beginning in educating the new officials.

According to the AEO, education is essential to efforts to keep the legislature focused on energy issues: "It is so hard to get them to understand energy" and the role it plays in the economy. Most of the education takes the form of one-on-one communication. When explaining the importance of energy conservation to lawmakers, the AEO staff use local examples. For instance, the AEO staff explain how savings from energy conservation measures can be used to improve the educational situation in the legislator's jurisdiction. The AEO staff relate energy savings to something that is important to the legislator or to his or her constituency.

Local communities also need to understand the economic benefits of energy conservation. According to the AEO, one-on-one communication and edacation with influential local leaders is effective in disseminating information about energy conservation.

From the AEO's point of view, the use of more energy efficient designs is happening "one step at a time" Education is the key. The AEO distributes a myriad of supporting material on energy-efficient design to builders. According to one contact, education "is the only tool we seem to have that works, but it's slow."

The AEO has other educational activities such as an outreach program for city officials and school districts. In a two-day program, the AEO explains the benefils of energy conservation and 
demonstrates various new products to city officials and teachers. "Every year it gets bigger and bigger." The AEO also offers similar programs for multihousing groups. Codes "will never get adopted without education up front."

\subsubsection{City Perspective}

\section{Barrlers to Code Adoption}

The lack of priority given to energy issues is one of the main barriers to the adoption of an energy code in the state of Arizona. According to one local building official, "No one is setting aside time, money or personnel for energy" so "it gets put at the bottom." Although information is disseminated to everyone, "no one is looking at the problem." In the local building departments, no one is assigned to energy. According to a local building official, the $A E O$ is the only organization actively pursuing a solution to the problem. She feels the AEO is disseminating valuable information, but not everyone is devoting attention to the problem. "Energy is not a priority and that's the key' to the problem. She feels the AEO has definitely tried to keep everyone notified about the energy situation.

At the city level, the building department is not viewed as an important department within the local governmental structure, especially if no problems arise. This situation is also noted in the literature: building officials are usually only noticed when problems arise; therefore, they bave an incentive to avoid problems (Field and Rivkin 1975; Oster and Quigley 1973). There are definitely no incentives for "rocking the boat."

Another reason codes have not been adopted is the universal reaction to change. According to a building official, a code has not been adopted primarily because "everyone dislikes change and the cost of change." Anxiety arises when people start asking, "What happens when a new system fails?" One building official stated that "a lot of dollars have been put into the current system that works." Whether or not the system promotes energy efficiency is not viewed as an important issue.
Another perceptual barrier is the code officials' view that the ASHRAE standard does not apply to their state. One building official stated that no code has been adopted in Arizona because the ASHRAE standards are oriented toward energy loss during the heating season rather than toward heat gain during the cooling season. Since Arizona is primarily concerned with heat gain, some people feel the ASHRAE standard is inappropriate for their area. Cities would adopt the energy standard, "If [code designers] got on the ball and made similar chapters for the energy gain season." Regardless of whether this statement is true, the fact that the local building official perceives it to be true is significant, especially if the official is in a position to influence the adoption of the code.

\subsubsection{Impact on Local Building Officials}

The local building officials in Arizona appear knowledgeable about energy conservation. Local building inspectors are familiar with the "devices and principals." Although they are not required to check for energy-saving features, local building officials verify that the devices have been installed as specified in the plan. The officials have become more aware of energy features as more information has been disseminated through the media and advertisements and through workshops and training programs. Officials also attend workshops and seminars, some of which discuss energy-conserving measures.

The building officials stated they could adjust to the incorporation of an energy code to their responsibilities. Although most building officials have not addressed the potential problems associated with the adoption of new codes, they would try to enforce them. "It would just be another thing they would have to handle." Although building officials do not currently inspect energy-conserving features in buildings, adopting an energy code would not be a burden to them. For instance, building officials have to check the insulation for fire safety, so checking it for energy code compliance would not seem to add a significant amount of work 
A new code would affect the timeframe for getting permits processed and the resources to accomplish the new tasks required under the code, but the building officials said they could adjust. Also, the building officials contend that the code would pose few problems because most builders are already constructing at energy efficient levels for both homes and commercial buildings. The building officials do not anticipate that a code would be much different than current building practices.

According to one official, building officials "are ready to go if the need arises." They have energy charts and know how to evaluate buildings. "Building officials have to look down the line to see what's coming....They can see the hand-writing on the wall, they just don't know when to read."

\subsubsection{Appropriate Methods for Encouraging the Adoption of Codes}

One building official firmly believed that one of the most effective methods for encouraging code adoption is to focus on city government officials. The local government's level of interest regarding energy codes or conservation measures needs to be assessed. "Ask them what they want," she suggested. Involving those "who can move and shake" in the adoption process is important because these people decide what their community needs, and they will be the ones to implement and enforce the codes. "Let them set the goals" because even little steps are progress, she argued.

The literature also addresses this issue: Several articles stress the importance of encouraging those who will be affected by the codes to be involved in how they are adopted and implemented (Crossman, 1986; Rowan, 1986). Early and extensive involvement will help the local community to "buy into" the idea. According to one building official, "you need to get the desire to do it at the local level and then work upwards to get resources." Past experience indicates that a statewide initiative would not work: "You set laws in place at the state level and nobody follows them." One local official did not feel "the mood is right among state legislators."
Arizona people "don't want to be fenced in." Most people do not like the idea of "Big Brother."

The general public should also be involved in the process, according to one contact. Arizona should be more positive and active in sending information out to the public. Although the public is invited to attend meetings and get involved, there is no encouragement or incentives to entice them to do so. One contact suggested that a centralized location for energy conservation information would help cтeate a "wider knowledge" and encourage more people to accept energy conservation measures.

Some cities, such as Peoria, have implemented energy conservation measures in city buildings. One contact stated that the driving force behind these decisions is that "we (building officials) are more convinced" that energy savings are important. They have "heard the arguments" and "know more about the problems down the line." Moreover, the city officials want to look better to their constituency by saving tax dollars and by getting recognition for doing so. The city officials want to set an example for private citizens.

\subsubsection{Architects' and Engineers' Perspectives}

All of the architects and engineers interviewed by PNL staff felt that energy codes would pose a problem in terms of cost. However, responses were mixed on whether the state should adopt energy codes.

One contact felt the extra amount of paperwork, time, and training required by a code would increase the cost of designing buildings. He claimed that the result of legislating commercial building energy codes is too much paper work and a bureau. cracy that takes up valuable design time, which absorbs money from architect's fees. Consequently, an energy code might put a significant number of design firms out of business. He also thought the codes might encourage designers to create designs that comply with the code but are not practical or well thought-out. Finally, he mentioned that "there are too many codes and overlapping jurisdictions." 
The same contact also claimed that "you can't legislate morality." Morality to him is saving and conserving energy through frugality and strong ethics. These types of principles should not be mandated by the govemment. Rather, the state should upgrade training programs for engineers and require more stringent qualifications for engineers in consulting firms.

Another contact, however, felt a code should be adopted and, in fact, had been pushing for it for 12 years. Owners and developers, however, are opposed to codes because of the perceived inctease in cost. This resistance, in tum, reduces the suppor for codes from the design community, which "has a very strong voice over Arizona's government."

The respondents offered several suggestions for a code. First, they would like one that was flexible enough to apply to different types of buildings. The respondents said they would like a performancebased code that would give them more freedom in their designs.

Second, architects and engineers feel that the interpretation of codes by building officials is a problem; however, the problem could be partially alleviated by simplifying the codes. One method of simplifying the codes would be to use language that is easy to understand.

Third, one conlact mentioned that codes are more likely to be adopted if the public is convinced of its value. He contended that once the public believes an energy code is important, politicians could be more easily persuaded to adopt a code.

Finally, implementing new codes in stages would be most effective. Compliance would be improved by introducing the codes one step at a time.

One contact mentioned that the Guidelines are outdated because the energy efficiency of buildings currently being built exceeds the guidelines by $10 \%$. Resources the architects use for building codes are mailings from state code officials; technical publications from PNL, ASHRAE, and Lawrence, Berkeley Laboratory; and conferences.

\subsubsection{Builders' Perspective}

The building contractors in Arizona have not given much thought to an energy code, yet they all speculated that codes would probably increase the cost of constructing buildings. This first impression of the effect of codes is an important issue to address when attempting to implement codes. Whether or not the code increases costs has little importance if some segments of the building community perceive this to be a problem.

One contractor stated that an energy code "wouldn't matter to us, unless it was so restrictive that owners couldn't build." According to the contact, if the codes added $25 \%$ to the cost of construction, many buildings could not be built. If the added cost of construction due to the codes was "sensible and justifiable," the contractors would accept the code.

The builders who were interviewed also indicated that an energy code would have little effect on them because architects determine the specifications of the building. According to one contact, "By trade, we are builders, not designers." Contractors "build to the plan--what's on the paper."

Although the architects specify many of the requirements of the building, the building contractors "do the footwork on the pricing scenarios" of the requirements and recommend the type of equipment or materials to use. According to one energy management contractor, energy operating cost is evaluated on every project. Several other building contractors mentioned that they calculate the projected initial costs and operating costs. For instance the building contractors conduct studies on different methods of cooling such as packaged air conditioning units, chillers, and cooling towers. Each method is evaluated in terms of initial cost versus operating costs. Lighting features are also analyzed. The contractors consider the minimum foot candles that are necessary for a given area, the heat gain from the lights, and the number of tubes to use in an area. 
According to most interviewees, the level of sophistication of energy efficiency equipment currently installed in commercial buildings varies by the client. The most important aspect to owners, however, is cost. Although the owners "are budget sensitive," they consider both initial and operating costs. The type of energy efficiency equipment and materials installed also varies by geographic location.

Responses were mixed to PNL's inquiry about the type of training required if a code was adopted. One interviewee felt some technical training on the controls of the system and proper installation methods would be necessary. He thought a reference manual might help, but it might also be obsolete because the technologies change so quickly. Training in the area of energy management "is the big key." That is, emphasis should be placed on why an energy system is necessary, how it works, and how to make it work most efficiently. Another contact said training might be necessary at the university level since many of their employees have degrees in architecture or engineering. However, another said the code would not induce the need for any extra training.

\subsection{CURRENT BUILDING PRACTICES}

According to state contacts, current building practices in the commercial sector could use definite improvements in energy efficiency. The builders and architecis "go for the glitz," rather than for energy efficiency. For instance, many of the commercial buildings are solid glass or have large atriums. The interviewees responded that "there's a lot of room for improvement." The most significant issue is cooling. Most commercial buildings have "terrible [energy] losses in windows." "It is hard to convince builders to use dual pane windows." Because it is not cold in Arizona, builders do not understand the need for well-insulated windows. The contacts reported that the builders do not realize that windows can keep the cool air in and the heat out. Another prominent issue is lighting. Buildings are "phenomenally over-lit."
The state contacts feel that any programs or efforts to increase energy efficiency in buildings should be targeted to architects and engineers since they are the ones actually designing the buildings. The AEO has done "considerable work with the engineers" by conducting workshops and by involving them in the AEO's Institutional Conservation Program.

One city building official feels most of the builders are building at energy efficient levels for both homes and commercial buildings. Commercial buildings "may not be as energy efficient as they could be." Lack of well-insulated windows is the biggest problem he could think of; however, insulation in ceilings is good. "Tenants are trying to save the cost of energy."

\subsubsection{Attitude of Utilities}

PNL staff contacted the three utilities that serve Arizona to determine their attitudes towards energy codes. PNL inquired about the utilities' energy conservation and educational programs, asked whether they supported energy codes, and assessed their familiarity with the Guidelines.

In general, the utilities offer basic conservation programs such as energy audits, time-of-use rates for commercial buildings, rebate programs on energy efficient equipment, and weatherization programs. Their educational programs consisted of bookless and educational programs in the schools and a few mini-courses on energy conservation. Most of their energy conservation outreach efforts focused on residential buildings rather than commercial buildings.

Most of the utilities had given very little thought to building energy codes and had limited knowledge about the Guidelines.

One contact, however, had definite opinions regarding the codes. He claimed utilities would support a "reasonable, flexible code" that "wouldn't affect the cost of the building. If it costs more, you will have a hard time cramming it down their 
[builders'] throats. You need to show benefits to the builders, building owner, and operator." Demonstrating "tangible benefiss" and the costeffectiveness of energy conservation are the most important aspects for the builders and building owners.

He feels the code would have to be a state code with "an awful lot of flexibility and diversity." Although input from the local level is important, the code "would have to come from further up than the local level." Enforcement, however, would have to occur at the local level, but "the impetus would have to come from the staten with economic incentives. A non-regulatory measure for encouraging energy conservation in buildings would be to offer construction credits or tax credits for innovative techniques. Anything "to make him [builder] go out on a limb" would help stimulate builders to in. clude energy conserving measures.

\subsubsection{University Education}

The University of Arizona offers courses, seminars, and lectures covering energy conservation. One course, "Solar Utilization in the Built Environment," covers energy policy and usage, how solar energy works, and models of solar applications. The material is oriented toward individual build. ings, groups of buildings, and communities. A seminar, "Tucson Solar Village," is offered as part of the Design Studio, an applied, year-long course that is required for all students.

The lecture series, "Crisis of Our Environment," focuses on the use of energy and related environmental issues. According to an architecture professor at the University of Arizona, "An architect needs to understand the community-scale issues, from global to national to citywide, and how to relate those issues to their work." The students "are challenged to think" about these issues and apply them to their designs. The professor "emphasizes solar as a technique in the context of resource use." Although an elective, the lecture series was wellattended.
According to the professor, the emphasis on energy conservation is not a new development in the university system. "We have been doing these things since the oil embargo." Although the University of Arizona has some "unique capabilities, we cannot claim to be the only school doing these things." The emphasis at the University of Arizona is desert architecture and design communication. Desert architecture focuses on "understanding the delicate resources" and how to design with them so that the resources are used responsibly. Design communication focuses on "understanding all issues and communicating them to the owners and the community." Conservation issues are definitely included.

When asked the prospect of adopting an energy code in Arizona, this professor said, "When it is sold as an environmental responsibility, then the owner or community will accept the idea." It must be shown that the codes are "adding something to the community" and presented as a way of "living in harmony with the environment." The Architecture School is a professional school; therefore, the program is "teaching students to be leaders in the community" and to be advocates for energy conservation and responsible resource planning.

He thought the prevailing feelings about the energy codes is based on pure skepticism. The codes are thought to be prescriptive, with no room for innovation or creativity. The "new frontier spirit" in Arizona does not want to be tied down to complying with restrictive regulations. He implied that the codes offer much more room for creativity than people assume.

In terms of energy conservation, "buildings have gotten a lot better, but there is room to go." When asked what that direction should be, he responded that "the problem is the way we finance buildings." Therc is a "low-cost, short-term focus with no sense of natural capital," the cost of which is not factored into the cost of constructing buildings. He feels definite attention should be paid to the cost of damage to the environment. 
Building energy codes pose a problem: They maintain a minimum standard and offer no incentive for individuals to respond to the bigger questions" of energy conservation.

The professor is on an energy commission that talks to politicians about this issue (that is, lack of incentives for energy conservation responsibility). According to the professor, politicians want to know how they can be adwocates for energy conservation awareness. The contact feels the answer is to encourage politicians or other groups to provide communities with information and goidelines for energy conservation policies.

We need a way to provide incentives for communities so individuals act responsibly.... Planning departments should be providing policies, strategies, methodologies for helping people understand the problems and provide ways to allow individuals to behave responsibly.
The public needs to be educated on the dangers of depleting natural resources.

\subsubsection{Role of Trade Associations}

The Electric League of Arizona (ELA) is a trade association for electric and energy management praclitioners. They have a heat pump council, government affairs office, training programs, etc. ELA gives awards to commercial builders for innovative energy efficiency in buildings.

They offer a course titted, Energy Management Seminar. The course is targeted for the Building Owners and Management Association, but members of their HVAC division, utility personnel, and building officials have attended in the past. They cover energy efficiency in HVAC equipment, windows, envelope, and lighting. 


\subsection{THE POTENTIAL FOR CODE UPGRADES OR ADOPTION OF ASHRAE/DOE STANDARDS}

PNL explored the potential for New Mexico and Arizona to upgrade the existing energy code or guideline and to consider adopting a codified version of the new ASHRAE or DOE standard for commercial buildings. The opinions of interviewees in each state are presented below.

\subsection{NEW MEXICO: POTENTIAL FOR CODE UPGRADE OR ADOPTION OF NEW STANDARDS}

Because New Mexico has a mandatory statewide energy code and has incorporated many aspects of the various MEC revisions, there is a strong likelihood that the code will be upgraded in the future. The prospect for the state to make the major change to the new ASHRAE/DOE residential and commercial standards is less clear.

\subsubsection{Prevailing Attitudes about Building Energy Conservation}

The final portion of the protocol addressing code adoption and updating asked interviewees about prevailing attitudes on energy conservation and about the likelihood that the state would adopt either ASHRAE 90.1 or the new DOE commercial building standard. The reactions of the New Mexico interviewees to these questions are discussed below.

Interviewees responded quite consistently when polled about the relative interest in energy conservation of five groups usually associated with energy code improvements: state legislature, contrac. tors, officials who enforce the code, large utilities, and $A \& E s$.

The state legislature tends not to reflect much concern for energy conservation in its activities, although it makes decisions about the funding level for various oil overcharge ${ }^{(a)}$ projects. One interviewee commented that the legislature tends not to be proactive in conservation because of its overriding concern for the health of New Mexico's construction and extractive industries, including oil; the legislature has also tended to focus more on New Mexico's high electricity rates (approximately 9 cents per $\mathrm{kWh}$ ) than on building energy efficiency.

According to the interviewees, the state's building community, in general, does not show much interest in energy conservation, except when directly affected (code revisions), although some contractors (particularly in residential construction) have used energy conservation features as a marketing tactic. One interviewee commented that the builders and contractors will "only put in what is required to comply, no more" (see also the previously mentioned paper in Appendix B).

Interviewees felt that local code officials generally show little independent interest in building energy conservation. Although "they generally do a reasonable job of inspecting buildings for energy code compliance," they are not seen as a likely advocate for code upgrade.

Interviewees commented that the state's larger utilities currently have an excess supply of energy and have shown little interest in promoting energy efficient construction to date. New Mexico's relatively high eleetrical rates have not had much of an impact on general support for building energy conservation. In part, this lack of impact can be attributed to the fact that gas is widely used for heating and that the most popular form of cooling tends to be evaporative cooling, which is relatively lowcost.

(a) Monies distributed to the states from the Petroleum Violation Escrow Account. 


\subsubsection{Adoption of the New Standards}

Opinions about the near-term (within two to five years) likelihood that New Mexico would upgrade its code to the level of ASHRAE 90.1 or the DOE standard were somewhat mixed. Only one individual (the DEMNR representative) felt that the state would be likely to go to the codified version of either standard in the near term. The other interviewees estimated up to 10 years for the state to upgrade its energy code, ${ }^{(a)}$ given the upgrade's perceived complexity and the significant changes it would require in current building practices (e.g., the size of framing members).

Several reasons were given: the state will likely stay with the MEC (however, if future MEC revisions are based on either new slandard, this may change); the climate for construction is currently very poor in New Mexico, and until it recovers, the state is unlikely to make more demands on builders; it would be very hard to change the energy code independent of the UBC change process; and the public is not interested.

\subsection{ARJZONA: THE POTENTLAL FOR CODE UPGRADE OR ADOPTION OF THE NEW STANDARDS}

The potential for Arizona to adopt a commercial building energy code is quite low. Contacts at the state energy office, who seem to have the best sense of current attitudes and would likely have responsibility for adoption and implementation, are not optimistic about the prospect of code adoption in Arizona. When asked about the possibility of a commercial building energy code, one respondent said it would definitely not be within the next two years. The state energy officer has been very involved with the state energy policy. She thought they "would be more receptive when the state energy policy is in place." She does not believe the legislature will "buy off" on the codes.

Surplus power, high vacancy rates, and the owners' and developers' resistance to codes will also hinder the adoption process. In addition to owners and developers, influential groups, such as architects, engineers, and builders, are opposed to the perceived cost impact of codes and believe building energy codes, in general, to have negligible value.

(a) These interviews were conducted just before Iraq invaded Kuwait in August 1990. Thus, interviewees were not considering any implications the invasion might have on the United States' energy siluation. 


\subsection{REFERENCES}

Crossman, P. L. 1986. "Model Conservation Standards - Lessons Learned from the Perspective of Designing and Managing Building Code Enforcement PTograms." ACEEE 1986 Summer Study on Energy Efficiency in Buildings, Volume 6. American Council for an Energy Efficient Economy, Washington, D.C.

Field, C. G., and S. R. Rivkin. 1975. The Building Code Burden. D. C. Heath and Company, Lexington, Massachusetts.

National Conference of States on Building Codes and Standards Inc. (NCSBCS). 1989. Directory of Building Codes and Regulations, Volume I Code Primer, Herndon, Virginia.
State of New Mexico (NM). 1988. New Mexico Enengy Conservation Code Applications ManualCommercial Buildings. 1988 Edition. Energy, Minerals and Natural Resources Department, Albuquerque, New Mexico.

Oster, S. M., and J. M. Quigley. 1973. "Regulatory Barriers to the Diffusion of Innovation: Some Evidence from Building Codes." The Bell Joumal of Economics: $361-377$.

Rowan, S. S. 1986. "Model Conservation Standards - Lessons Learned in Providing Technical Support to the "Building Code Industry." ACEEE 1986 Summer Study on Energy Efficiency in Buildings, Volume 6. American Council for an Energy Efficient Economy, Washington, D.C. 

APPENDIX A

QUESTIONNAIRES 


\section{A\&E FIRMS}

Note: * Items will be obtained at the end of the interview.

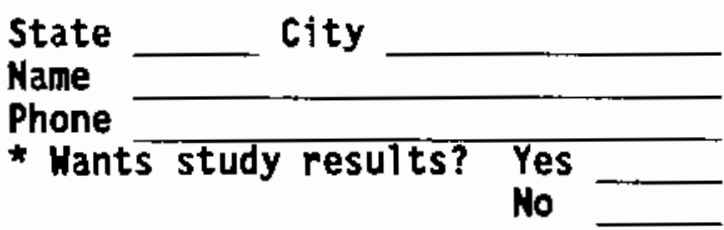

Interviewer
Organization

Title

* Mailing address

Date of Interview

\section{INTRODUCTION}

Hello, my name is , and I work for Pacific Northwest Laboratory in Richland, Washington. PNL is a national research laboratory for the U.S. Department of Energy.

We are conducting a study for the DOE on the adoption and implementation of state commercial building energy codes. We are interested in learning about your experiences with current commercial building energy codes, and your opinion about several code compliance and enforcement issues. The information we gather will be used to design programs that will assist states to adopt and implement new codes. I have a series of questions that we are using to gather information. Would you be the appropriate person to speak with?

(If not) Whom would you recommend I speak with?

(If yes) The questions I have should take about 15 to 20 minutes to answer. Is this a convenient time for you to talk with me? (If not) Is there another time that is more convenient?

\section{COMPLIANCE}

In the first series of questions, we are interested in understanding some of the compliance issues associated with the commercial building energy codes currently in place.

QI In what states does your firm regularly do business?

Q2 Do you interact with building code officials for any of the following activities?

plan reviews gathering information on new codes design assistance building inspections 
Q3 How long have you been involved in designing commercial buildings?

$$
\begin{aligned}
& 0-2 \text { years } \\
& 2-5 \text { years } \\
& 5-10 \text { years } \\
& 10+\text { years }
\end{aligned}
$$

At this point, I would like to ask you some questions about the steps taken by architects to adhere to the commercial building energy code in

(BE SURE RESPONDENT SPECIFIES STATE (AND JURISDICTION, IF NECESSARY) AS CODES MAY VARY.)

\section{Design Phase:}

Q4a What code requirements for the BUILDING ENVELOPE (sides and roof) are the easiest to comply with?

Q4b What code requirements for the BUILDING ENVELOPE are most difficult to comply with?

Q5a What code requirements for the MECHANICAL SYSTEMS are easiest to comply with?

Q5b What code requirements for the MECHANICAL SYSTEMS are most difficult to comply with?

Q6a What code reqirements for LIGHTING are easiest to comply with?

Q6b What code reqirements for LIGHTING are the most difficult to comp?y with?

Q7 Are your opinions shared by others in your office?

$\varlimsup_{\text {If no, please explain. }}^{\text {No }}$


Q8 Do your designs generally exceed the minimum commercial building energy codes for:
building envelope?
Yes
$\ldots$ Nos
$\longrightarrow$ No
mechanical systems?

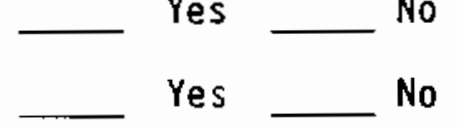

Q9a What features of the commercial building energy code do code officials enforce most rigorously for the BUILDING ENVELOPE?

Q9b What features of the commercial building energy code do code officials enforce least rigorously for the BUILDING ENVELOPE?

Q10 What features of the commercial building energy code do code officials enforce most rigorousiy for the MECHANICAL SYSTEMS?

Q10b What features of the commercial building energy code do code officials enforce least rigorously for the MECHANICAL SYSTEMS?

Q1la What features of the commercial building energy code do code officials enforce most rigorously for the LIGHTING?

Q11b What features of the commercial building energy code do code officials enforce least rigorously for the LIGHTING?

\section{Inspection Phase:}

Q12 Are staff in your office involved with building inspections?

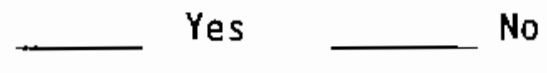

Q13a What are the most frequent types of energy code problems discovered by building inspectors for the building envelope?

Q13b What are the most frequent types of energy code problems discovered by building inspectors for the mechanical systems?

Q13c What are the most frequent types of energy code problems discovered by building inspectors for the lighting?

\section{A. 3}


Q14 What are some of the more common problems your office encounters with its efforts to comply with the commercial building energy code?

\section{TRAINING AND EDUCATION}

Q15 What training was provided to the staff in your office to learn about new commercial building energy codes and who provided the training?

Provided by

SEO

Utility

Other

Format

Classes

Written information

Demonstrations

Q16 What additional training might help you perform your review and inspection responsibilities better?

Q17a Do local building officials have adequate knowledge of commercial building energy codes?

Yes No No

Q17b If no, what recommendations do you have for improving their knowledge?

\section{FACTORS FACILITATING COMPLIANCE}

Q18a Do you have adequate resources to incorporate the commercial building energy codes into your designs?

Yes №

Q18b If no, what resources could help you better incorporate the commercial building energy codes into your designs?

\section{CHANGES}

Q19 What changes would you like to see made to your commercial building energy code? 
Would you like to receive the results of the study?

Yes ﹎ㅡㄴ No

Mailing address:

A. 5 


\section{STATE ENERGY OFFICE}

\section{CODE STATUS}

Q1 When was your current commercial building energy code adopted?

Q2 What standards or model codes are the basis for your current commercial building energy code?

MCEC Model Code for Energy Conservation in New Building Construction MEC Model Energy Code

ASHRAE $90-75$

ASHRAE 90A-80

NECC National Energy Conservation Code

other (Specify, particularly if it was state-developed)

Q3a What specific features of your current commercial building energy code do you feel are particularly effective/good?

Q3b Why?

Q4 What changes do you feel should be made to your current commercial building energy codes?

Q5a Is your commercial building energy code reviewed/updated on a regular basis?

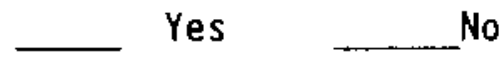

Q5b If yes, how often?

Q6a Can local governments modify/amend the state commercial building energy code?

Yes No

Q6b Please explain.

(SEO only) Can you send us a copy of the current code? 


\section{ADOPTION}

The next series of questions concerns the process by which your current commercial building energy code was adopted.

Q7a During the adoption process of your commercial building energy code, did you make any modifications to (the model code check abovel? Yes No

Q7b If yes, please explain what modifications were made, and why.

Q7d Who made them? (e.g., sponsoring agency, legislature (committee or entire legislature)

Q8 What technical aspects of the code were most controversial during the most recent adoption process, and why?

[Also probe to identify who was involved]

Q9 I'm interested in knowing what groups were involved in the code adoption process.

I have a list of the types of organizations that often get involved in building code legislation. As I read from the list, please give me the name of any organizations that you recall being involved, and whether they were very involved, somewhat involved or minimally involved. It would also be helpful if you could give me a contact name and phone number for the groups that were involved. 
a. State Energy Office

b. Name and phone

b. State legislature Name and phone

c. govt. agency/special comm.

d. Utilities Name and phone

Name and phone

e. Citizen community groups

f. Environmental proups

g. A\&E firms Name and phone

Name and phone

h. Builders/Contractors

i. Developers Name and phone

j. Name and phone

j. Local code officials

k. Realtors Name and phone

1. Manufacturers/suppliers

m. Other Name and phone

Name and phone

Q10 Would you please briefly explain the role your organization played in the adoption of the current commercial building energy code. I will read from a list of possible roles:

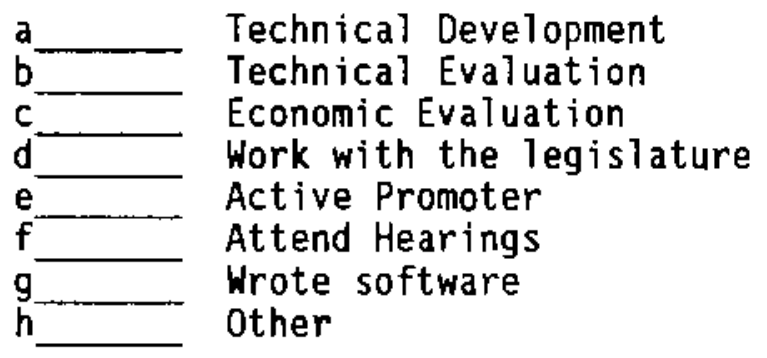

Q11a In your opinion, what one group was particularly important in getting the current commercial building energy codes adopted, and why? 
Q12 What groups or organizations opposed the adoption of the current commercial building energy codes? (e.g., builder groups, gas utilities, etc.)

Q13a In your opinion, were there other groups or organizations that did not participate in the adoption process that should have?

Yes No

Q13b Who are they and why should they have been involved?

Q14 We are interested in understanding the administrative impacts that may accompany energy code adoption or updating.

Q14a What effects did the effort to adopt or upgrade the current code have on your organization's staff or workload?

Q14b How did your organization cope with these impacts?

Q15 I would like to get your opinion of the attitude that various groups in your state hold toward the efficient use of energy in commercial buildings. As I read a list of important groups, how would you rate their level of concern? The choices are very concerned; somewhat concerned; not very concerned; and not at all concerned. Please explain or give examples.

$$
\text { Very Somewhat Not very Not at all }
$$
a. State Tegislature
Explanation:
b. State energy office
Explanation:
c. Builders/Contractors
Explanation:

d. Local code enforcement officials

Explanation:

e. Gas \& Electric Utilities

Explanation: 
Q16 What specific problems or issues, if any, did your organization have with the current commercial building energy codes as they were being considered for adoption?

Q17 From your perspective, what specific problems or issues did other groups, such as the ones we have mentioned (for example, builders, utilities, and realtors) have with these codes during the adoption process?

Q18 What legal issues or problems, if any, arose during the adoption process for your current commercial building energy codes?

Q19 In your opinion, which of the following problems were the most difficult to resolve during the code adoption process?
a. political issues (e.g, property rights)
b. financial issues (e.g., the cost of compliance)
c.
d. the public's lack of knowledge or indifference
e. consumer resistance
f. builders' lack of knowledge
other

Q19a Could you please explain your response? 
LOCAL BUILDING CODE OFFICIALS

State

Name

Phone

$\begin{array}{ll}\text { Wants study results? } & \text { Yes } \\ \text { No }\end{array}$

Interviewer

INTRODUCTION
Organization

Title

Mailing address

Date of Interview

Hello, my name is and I work for Pacific Northwest Laboratory in Richland, Washington. PNL is a national research laboratory for the U.S. Department of Energy.

We are conducting a study for the DOE on the adoption and implementation of state commercial building energy codes. We would like to get some information about your experience with energy code compliance and enforcement in your jurisdiction. The information we gather will be used by DOE to design programs that will assist states to adopt and implement new energy codes. I have a series of questions about energy code enforcement that we are asking code officials in several different jurisdictions across the state. Would you be the appropriate person to speak with?

(If not) Whom would you recommend I speak with?

(If yes) The questions I have should take about 15 to 20 minutes to answer. Is this a convenient time for you to talk with me? (If not) Is there another time that is more convenient?

\section{ENFORCEMENT}

QA Are you involved in the enforcement of commercial building energy codes? (ptan approval and/or building inspection)

Y.. Yes No

If no, try to get another name and terminate conversation.

QB What is the code enforcement jurisdiction of your organization (i.e., what communities are included)? What is its population?

QC About how many commercial building permits does your office issue annually? 
QD What is the most common type of commercial building being constructed in your jurisdiction at the present time? (office, retail, warehouse, high rise apartment, school/assembly)?

*is this a trend?

The least common?

I would like to ask you a few questions about your background. First of all, what is the name of the office in which you work? What is your title?

Q1 Would you please briefly explain your job responsibilities as they relate to commercial building energy code enforcement for building envelope, mechanical systems and lighting?

Building Mechanical

Envelope $\quad$ Systems Lighting

P]an review

Building inspections

Other

Q2 How long have you been in your current job?

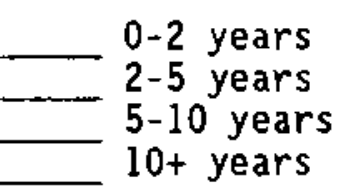

Q3 What training or previous work experience is required for your job?

Degree

Certification/registration

Years of experience

other

* is this common for people in your position around the state?

Q4 What percent of the building code officials in your office have previous experience working in building construction?

$0-10 \%$
$10-25 \%$
$25-50 \%$
$50 \%$ and more

A. 12 


\section{PLAN APPROVAL}

Q5a Do staff in your office review plans?

Yes __ No - - If no, who does?

Q5b If yes, how many staff do you have for each of the following categories?

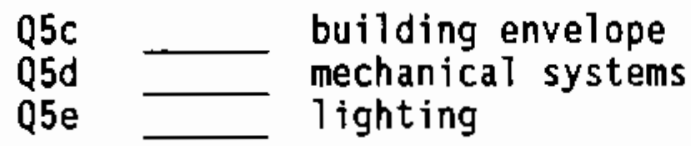

Q6 What aspects of the commercial building energy code do you feel are most important for enforcement purposes in your local jurisdiction?

Q7a Is your opinion shared by others in your office?

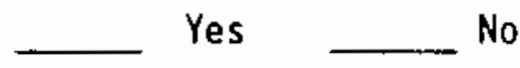

Q7b Please explain.

Q8 What aspects of the commercial building energy code do you feel are least important for enforcement purposes in your local jurisdiction?

Q9a Do you think your opinion is shared by others in your office?<smiles></smiles>

Q9b Please explain.

Q10 What problems or difficulties with the current commercial building energy code do you most frequently encounter when reviewing plans? Please explain.

Q10a building envelope:

Q10b mechanical systems: 


\section{Q10c lighting systems}

* What would you say is the reason for the success/problems in compliance with the code at the plan review stage? 


\section{Building Inspections}

Q11a Do staff in your office conduct building inspections?

Y.__ Nos - N If no, who does?

Q11b If yes, how many staff do you have for each of the following categories?

building envelope

mechanical systems

- lighting systems

Q12 What problems or difficulties with the commercial building energy code do you most frequentiy encounter when inspecting buildings?

Q12a building envelope:

Q12b mechanical systems:

Q12c lighting:

*What would you say is the reason for the success/problems with compliance at the inspection stage?

Q13 Do you ever withold issuance of an occupancy permit due to non-compliance on energy code requirements? Please explain.

*temporary permit 


\section{Training and Education}

Q14 How are staff trained to review plans and inspect buildings for energy code compliance?

\section{Provided By:}

SEO

Utility

other

Format

Classes

Written information

Demonstrations

*frequency of training programs

*support from employer (City)

Q15 What additional training might help you perform your review and inspection responsibilities better?

Q16a Do architects/engineers and builders/developers have adequate knowledge of commercial building energy codes?

Yes No

Q16b If no, what recommendations do you have for improving their knowledge?

\section{Factors facilitating enforcement}

Q17a Does your office have adequate resources to enforce the state commercial building energy codes

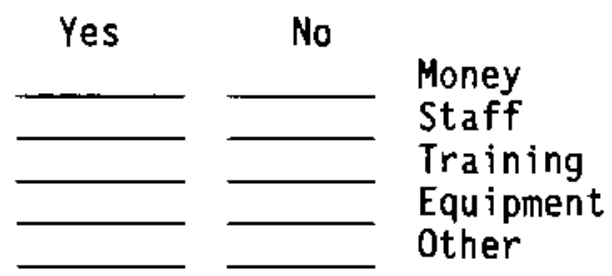

Q17b If no, what resources could help you better implement the building codes? 
Q17c of the resources you lack, which do you believe is the most important for effective enforcement of commercial building energy codes?

\section{Code Changes}

Q18 What changes would you like to see made to your commercial building energy codes?

Q19 How are you informed about revisions to your code?

Q20 Have you been involved in the past with the adoption or revision of energy codes?

Y Yes No

Q20b If yes, please explain.

Thank you for taking time to answer these questions. Would you like a copy of the results of the project?

Yes No If yes, get mailing address and include in ID 



\section{APPENDIX B}

PASSING WITH A "D" IS FAILURE 


\section{PASSING WITH A "D" IS FAILURE}

Flexibility of the Model Energy Code in Building Design:

New Mexico Experience

Kar] E. Scheuch, P.E. Bovay/McGinty, Inc.
Robert D. Busch, Ph.D., P.E.

RD Busch \& Associates

\section{INTRODUCTION}

In 1977, as part of a program to encourage energy conservation, the State of New Mexico adopted Appendix Chapter 53 of the Uniform Building Code (UBC). The State realized that adoption of a new code requirement by itself would not save energy, so the State developed an applications manual and carried out training workshops in support of the program prior to its implementation. The program was a success.

In 1986, the State of New Mexico adopted the 1985 edition of the UBC which included the 1983 edition of the Model Energy Code (MEC). The 1986 edition of the MEC automatically superseded the 1983 edition and became part of the New Mexico Building Code (excluding Sections 505 and 605 covering 1 ighting) in 1988.

In the spring of 1988, the New Mexico Energy, Minerals and Natural Resources Department issued a contract to Bovay Engineers, Inc. (now Bovay/ McGinty, Inc.) for updating of the New Mexico Energy Conservation Applications Manual and training on its use. The source of the funding was oil overcharge monies distributed to the State of New Mexico. Specifically, the goal of the project was to update the existing applications manual and conduct training in various locations for code officials, architects, engineers, and contractors.

The old applications manual contained information on both residential and commercial building applications but was oriented toward the residential builder. 
The authors decided to split the new manual into a commercial building manual and a residential building manual to simplify the use of the code and to allow each manual to specifically address those items unique to each type of construction.

As a result of the authors' experience in developing and complying with state energy codes, a number of changes to the applications manual were included in the update. These were intended to facilitate compliance and clarify applications of the Model Energy Code specific to its implementation in New Mexico.

Specific improvements included:

- Development of graphic tables which detailed typical wall and roof sections and the associated U-values (see Figure 1).

- Development of tabular data for particular New Mexico locations in lieu of the nondiscrete graphs in the MEC.

- Development of the New Mexico climate zones to avoid the need for interpolation.

- Development of a table showing maximum allowable skylight area for various locations.

- Development of trade-off forms for analys is of allowable trade-offs, e.g., wall versus roof insulation.

- Development of a code verification checklist to show code compliance. The second phase of our work dealt with conducting training sessions in two New Mexico locations. Each training session was geared toward a specific audience. Those for the code officials dealt with the requirements of the MEC as adopted in New Mexico, while those for the contractors, builders, architects, and engineers spent more time on compliance issues. The overall goal of the 


\section{R-11 STUCCD WALL}

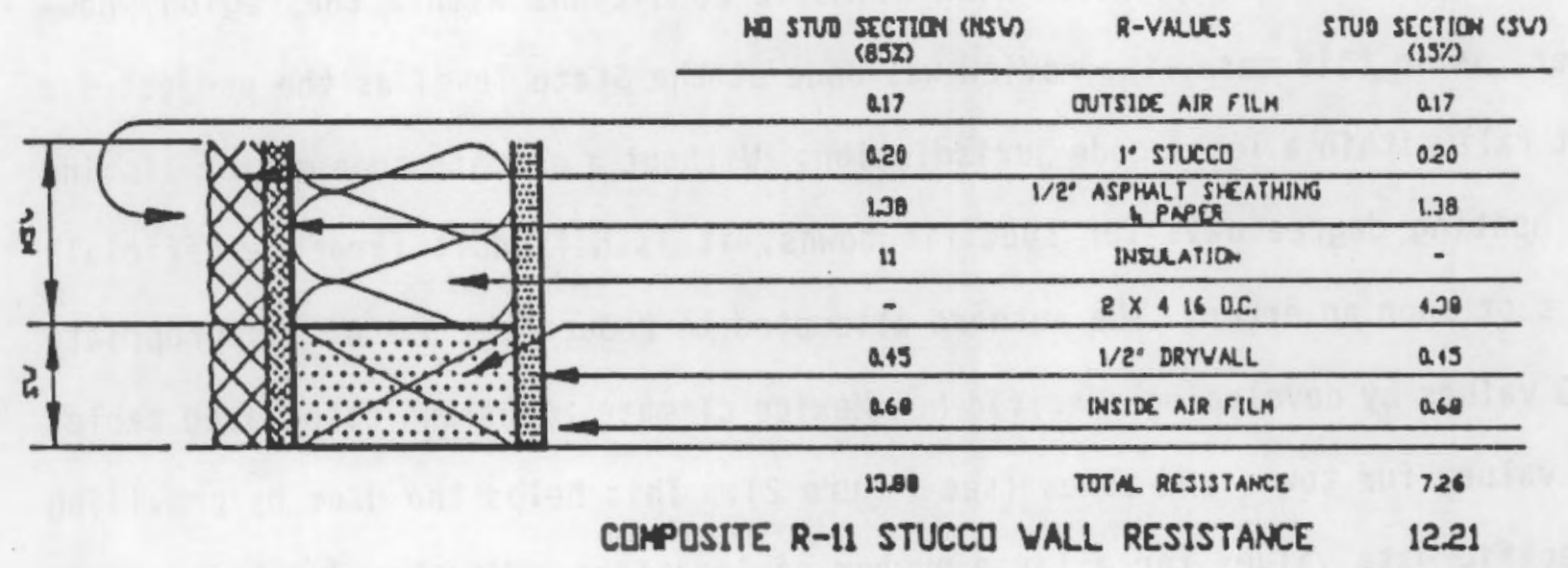

Figure 1. Typical Wall Section 
training sessions was to explain the changes in the new code, to demonstrate the application of the code for specific examples in specific climate zones, to introduce the compliance checklist, and to encourage use of the code.

\section{MISAPPLICATIONS OF THE CODE}

In our review of examples of code compliance, several misapplications came to light which guided our development of the manuals. One specific example which illustrates a number of issues was an energy code analys is on a new school in western New Mexico.

The first error occurred when the architect selected the incorrect value of heating degree days (HDD). The architect used a $H D D$ value of 4300 which does not apply to any of the towns in the vicinity. The actual value is 6500 while the value for the nearest town is $6200 \mathrm{HDO}$. In many cases the code official is local and is well acquainted with climatic conditions within the region, however, as in this case, the review was done at the State level as the project did not fall within a local code jurisdiction. Without a climate zone map or listing of heating degree days for specific towns, it is difficult for code officials to spot such an error. The authors attempted to reduce the use of inappropriate HDD values by developing specific New Mexico climate zones and associated tables of values for towns and zones (see figure 2). This helps the user by providing specific data values for a large number of locations. We also developed a map which can be used to identify the closest HDD location to the proposed building site.

A second error occurred when the architect traded off wall insulation for slab-on-grade floor insulation - a trade-off excluded by Section 502.1.1 of the 1986 Edition of the Model Energy Code. To solve this problem, the authors provided examples within the applications manual which specifically addressed 


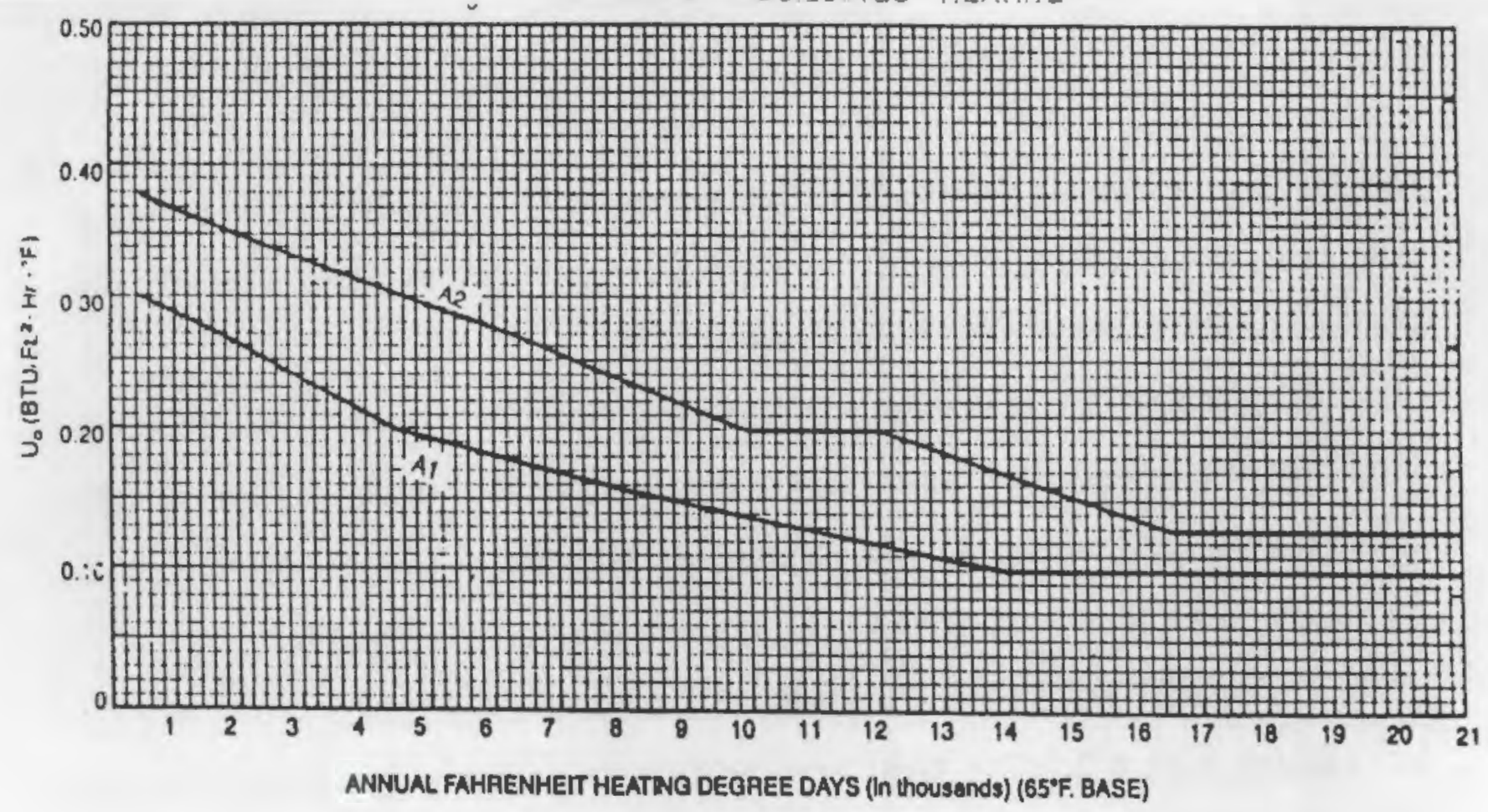

FOR RESIUENTIAL BUILDINGS IN NEW MEXICO

Maximum $U_{0}$-Values Allowed By Code and Minimum R-Yalues for Slab on Grade Insulation

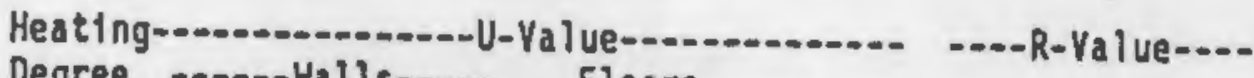

Degree -...--Halls-....- Floors

City Oays Detached Other Unhtd, Roof \& $65^{\circ} \mathrm{F}(A-1) \quad(A-2)$ Spaces Cellings Heated Unhtd.

$\begin{array}{llllllll}\text { Al amogordo } & 3053 & 0.24 & 0.33 & 0.18 & 0.050 & 4.9 & 3.0 \\ \text { Albuquerque } & 4332 & 0.20 & 0.30 & 0.09 & 0.050 & 5.9 & 3.8 \\ \text { Artesia } & 3366 & 0.23 & 0.32 & 0.16 & 0.050 & 5.1 & 3.2 \\ \text { Carlsbad } & 2813 & 0.24 & 0.33 & 0.20 & 0.050 & 4.7 & 2.8 \\ \text { Carrizozo } & 4234 & 0.21 & 0.31 & 0.10 & 0.050 & 5.8 & 3.8 \\ \text { Chama } & 8254 & 0.15 & 0.23 & 0.08 & 0.033 & 8.8 & 6.5 \\ \text { Clayton } & 5150 & 0.19 & 0.29 & 0.08 & 0.047 & 6.5 & 4.4 \\ \text { Cloudcroft } & 7205 & 0.17 & 0.25 & 0.08 & 0.037 & 8.0 & 5.8 \\ \text { Clovis } & 4033 & 0.21 & 0.31 & 0.11 & 0.050 & 5.5 & 3.6 \\ \text { Corona } & 5389 & 0.19 & 0.29 & 0.08 & 0.046 & 6.6 & 4.5 \\ \text { Cuba } & 7122 & 0.17 & 0.25 & 0.08 & 0.037 & 7.9 & 5.7 \\ \text { Ueming } & 3347 & 0.23 & 0.32 & 0.16 & 0.050 & 5.1 & 3.2 \\ \text { Eagle Nest } & 9254 & 0.14 & 0.21 & 0.08 & 0.033 & 9.5 & 7.1\end{array}$

Figure 2. Tabular Presentation of MEC Graphical Data 
the issue of trade-offs among building components. In addition, a series of compliance checklists and forms were provided for the users which give instruction as to which trade-offs are allowed.

However well the authors did in developing solutions to potential problems, in developing an easy to use applications manual, or in conducting training for potential users, there still remain problems inherent in the Model Energy Code that need to be addressed directly by the national code community. PROBLEMS INHERENT WITHIN THE FRAMEWORK OF THE MODEL ENERGY CODE

1. Passing With a 0 . The first problem that the authors encountered was the easy acceptance by both the code officials and the building design community of buildings which just barely comply with the MEC. In the course of developing examples for the applications manuals, the authors found that a residence with $13 \%$ of the floor area as glazing and a minimum wall surface area just barely complied in a $6200 \mathrm{HDO} \mathrm{climate.} \mathrm{However,} \mathrm{if} \mathrm{the} \mathrm{design} \mathrm{was} \mathrm{altered} \mathrm{to} \mathrm{include}$ substantially more wall surface area (e.g., addition of a number of corners and cutbacks), the design easily complied. In either case, there was a minimal amount of wall insulation and a significant area of north facing glazing (e.g., to allow for a view of the mountains). Both structures complied; both would probably create significant discomfort for occupants sitting near the north glass in the winter; and most importantly, neither structure was particularly energy efficient.

The problem arises primarily due to a lack of education in the difference between the philosophy of an energy code and that of a health and safety code. If a structure meets a health and safety code, then it is deemed safe - there are no levels of more safe, or safest. However, with an energy code, compliance 
usually means the bare minimum of energy conserving options. There are probably a number of economical approaches and options which can be added to a complying structure to make it more energy efficient. Thus, compliance is really not sufficient if we are searching for energy efficiency.

Compliance with the energy code is analogous to passing a test in school with a $D$; you passed, but it is nothing to shout about. Unfortunately, in the energy game, grades are not given; it's only a matter of pass/fail. This problem may be traced back to the question of prescriptive versus performance standards. Prescriptive standards detail the specific features of the design, for example R-11 batt insulation in a $2 \times 4$ cavity wall. In contrast, performance standards establish performance requirements either in energy use per year or through the assignment of "points", where points are related to energy dollars saved through the installation of particular energy saving measures. The advantage of the performance method is that the customer can identify the grade or the energy efficiency of the structure, while the advantage of the prescriptive method is that the builder can quickly determine compliance and then label any complying house as "energy efficient."

2. Foundations Are Not a Strong Part of the Code. Because heat transfer to the ground has been difficult to model and not easy to characterize in a prescriptive format, insulation requirements for foundations have lagged behind those of other components. As of the 1988 Amendments to the MEC, there are no requirements for insulation or thermal performance on basement walls or floors if these enclose unconditioned spaces. If the space is conditioned, walls have to meet the same requirements as exterior walls, and floors must be insulated to R-12 in most areas of the country. This is an obvious problem where there are no adequate construction details for R-12 insulation below a slab, basement floor. These 
requirements may be energy conservative, but without details for installation, much of the energy savings opportunity may be negated by poor detailing during construction.

A similar problem arises with slab insulation; the MEC is fairly specific as to the amount but leaves the details up to the builder. Problems with installation include:

- If the insulation is placed on the outside of the stem wall, there may be problems with damage before finished grading and stucco or face brick application, for example (see Figure $3 A$ );

- If the insulation is placed between the slab and stem wall, there may not be adequate width for anchoring the sole plate or carpet strips (see Figure $3 B)$; and

- Although the code requires a depth of 24 inches below grade, in many areas the footing depth requirement is much less. This either requires a major change in traditional construction practice or leaves six inches of insulation dangling in the ground where it is unlikely to last beyond the fill and compaction, if the contractor is even willing to overexcavate.

Another problem arises with a new construction type - that of posttensioned slabs. Normally, the contractor wants to pour the entire slab at once including the garage and patio so that post-tensioning is done for one unit. Therefore, any slab insulation cannot occur at the building thermal barrier. Code precludes trade-offs of slab insulation with anything else so code officials are faced with a dilemma either allow the contractor to build without the insulation or create an artificial trade-off and require thicker slab insulation or additional wall insulation. 

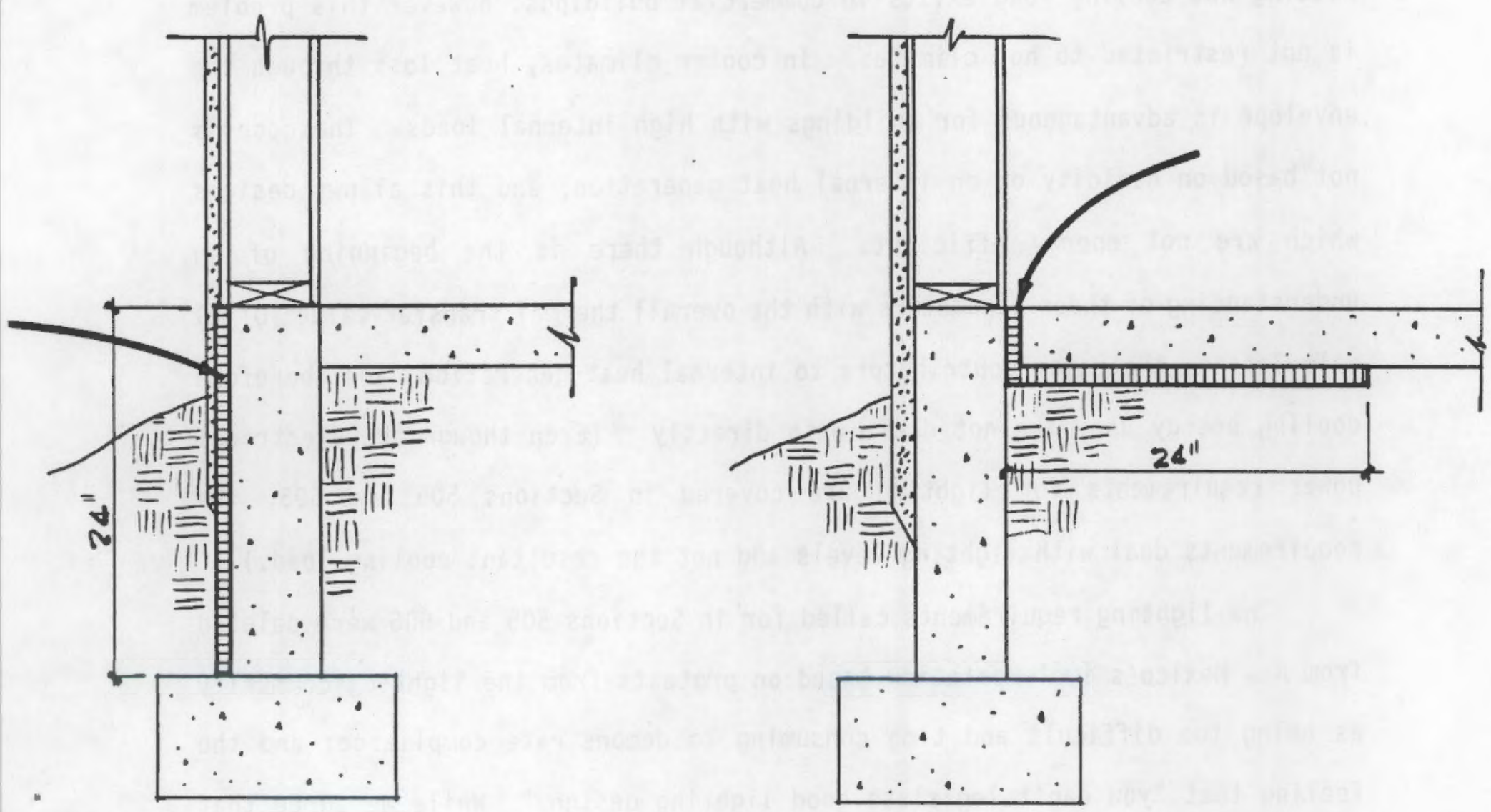

Figure 3A. "Exterior" Application of Slab Insulation

Figure 3B. "Interior" Application of Slab Insulation 
3. Other Residential Problems Which Appear To Be Here To Stay. The code requirements are driven by heating, not cooling. This creates significant problems in lower latitude areas with minimal heating, e.g., Arizona, Florida, South Texas. The code may require insulation levels in walls and/or roof/ceilings that actually keep in more internal heat and aggravate the cooling problem. Somehow the prescriptive requirements need to address this issue in cooling dominated $\mathrm{climates.}$

4. Commercial Problems. The same problem with respect to the code controlling heating not cooling load exists in comnercial buildings, however this problem is not restricted to hot climates. In cooler climates, heat loss through the envelope is advantageous for buildings with high internal loads. The code is not based on humidity or on internal heat generation, and this allows designs which are not energy efficient. Although there is the beginning of an understanding of these parameters with the overall thermal transfer value (OTTV) calculation, the major contributors to internal heat generation, and therefore cooling energy use, are not dealt with directly. (Even though the electrical power requirements for lighting are covered in Sections 505 and 605, the requirements deal with lighting levels and not the resultant cooling load.)

The lighting requirements called for in Sections 505 and 605 were deleted from New Mexico's implementation based on protests from the lighting community as being too difficult and time consuming to demonstrate compliance; and the feeling that "you can't legislate good lighting design." While we agree that no standard is a guarantee of good design, we suggest that some definitive guidelines on a watt/square foot basis would certainly give the designer targets to strive for and are good indicators of energy efficient lighting levels. 
Why do we care about these problems? Certainly the builder/designer can choose the 5ystems Analysis Approach (performance based calculation) to comply unusual bulldings or those whtch are energy efflclent. However, this takes time and money. The reality is that most will take the path of least resistance, complying prescriptively - creating a building that is not energy efficient but does comply. Another case of passing with a $D$ but failing to make the building energy efficient.

\section{RECOMMENDATIONS}

We have identified a number of problems or issues with the current Model Energy Code. This does not mean that the MEC is useless. On the contrary, it has been the major force in identifying energy as an issue of concern to the building community. Just by doing compliance, builders, designers, and others are made aware of where energy uses occur and some techniques for reducing these are identified. Our purpose with this presentation is to provide some suggestions on how to strengthen the code without increasing the time required for its application. Clearly, the goal of any code should be ease of implementation.

The problems identified seem to come from two sources: a lack of clarity in code requirements and a lack of comprehensiveness in scope. The lack of clarity issues can be easily solved by the implementing jurisdictions. When the MEC is adopted by a local jurisdiction, there needs to be some additional work done to create an "applications" manual for that area. Too often jurisdictions just adopt the code and leave it to those in the field to interpret it. This leads to neglect of many of the code requirements. By providing a few pages of clarification, the jurisdiction could solve many of the grey areas by: 
- Providing for discrete values of insulation that are commercially avallable, for example, prescriptive levels should be R-5 or R-11 or R-13, not an R-4.7 or R-16.

- Providing figures with U-values for typical, local construction components, e.g., R-11 wall, R-30 ceiling, joist ceiling with R-19, etc.

- Tabulating values for walls, roof/ceilings, floors, etc. for major locations within each jurisdiction (state). This eliminates errors/discrepancies when trying to read from a graph and ends arguments as to what the HOD for a particular location is. Providing climate zone maps for extension beyond major cities.

- Defining a compliance checklist - this could be copied and put on sticky-back so that compliance can be easily verified from $p l a n s$ and becomes part of the record drawings.

A few pages of clarification generated at the time of implementation of the code will increase the number of users who correctly comply with its requirements. Unfortunately, this will not increase the passing grade from a $D$ to anything higher. It is certainly a substantial step forward to increase the rate of compliance, but as we found in New Mexico, education and training are also required to promote better energy efficient design. The jurisdiction, or a group of jurisdictions, needs to create seminars or training sessions which educate designers and indicates to them that compliance often means passing with a $D$, but that it is not the path to optimum energy efficiency. Energy efficiency begins with an understanding of how the particular structure uses energy and then is implemented through a design which effectively responds to climatic, functional, and economic constraints. 
The second part of the solution involves a serious look at some of the deficiencies within the code. This has to be addressed at the national level. Besides providing requirements for basements and new foundation types, there needs to be an addendum of construction details which indicate the better ways of installing the insulation. Only with the details can we be assured that the installation provides for the energy efficiency which was expected when the code was created. We also need to investigate how to integrate additional parameters which have significant impact on energy use. Somehow we need to take into account internal load effects, the writing of simple guidelines regarding lighting, and the impact of humidity on cooling energy use. We are of the opinion that the major impact of the code is getting these issues before the building community. The prescriptive requirements don't need to be that stringent initially, but they do need to be explicitly stated so the designers become aware of the effect of other parameters on energy use.

The bottom 1 ine is one of education and clarity. If the requirements are clear and precise, then compliance becomes less time-consuming, and there is a higher percentage of those complying. Because energy efficiency is a complex issue, simple, prescriptive guidelines don't address all the problems, but they are a first step in the education process. After the first step, education must extend beyond the focus of an energy code. We are all aware that you cannot legislate good design, but you can provide the background and intuitive understanding of the processes which allow the designers to create energy efficient structures without limiting their design flexibility. Only in this way can we convince designers that compliance alone is not energy efficient, and that passing with $a$ is faiture in the attempt to conserve energy. 
* 


\section{DISTRIBUTION}

No. of

Copies

\section{$\underline{\text { OFFSITE }}$}

12 DOE Office of Scientific and Technical Information

J. P. Milhone Office of Building Technologies CE-13

U.S. Department of Energy 1000 Independence Avenue Washington, DC 20585

F. H. Abel

Office of Planning and Assessment

U.S. Department of Energy 1000 Independence Avenue Washington, DC 20585

\section{J. LaMontagne}

Brookhaven National Laboratory Building 475

Upton, NY 11973

B. Farhar

Solar Energy Research Institute Portal Building 409 12th Street, S.W.

Suite 710

Washington, DC 20024
No. of

Copics

\section{J. Boulin}

Office of Building Technologies

CE-13

U.S. Department of Energy 1000 Independence Avenue Washington, DC 20585

\section{ONSITE}

\section{DOE Richland Operations Office}

R. Goranson

28 Pacific Northwest Laboratory

R. C. Adams

J. M. Callaway

D. E. Deonigi

R. E. Jarnagin

A. K. Nicholls

T. J. Secrest

D. L. Shankle (10)

E. J. Stenehjem

A G. Thurman (5)

Publishing Coordination

Technical Report Files (5) 
$\bullet$ 